\section{A 伊aper}

on

\section{"OPTIC NEURITIS," "CHOKED DISC," OR "PAPILLOEDEMA":}

\section{TREATMENT, LOCALIZING VALUE, AND} PATHOLOGY.

Delivered before the Section of Ophthalmology of the British Medical association at Belfast.

BY SIR VICTOR HORSLEY, F.R.S., F.R.C.S., SURGEON TO THE NATIONAL HOSPITAL FOR THE PARALYSED AND EPILEPTIC, QUEEN SQUARE, AND CONBULTING SURGEON TO UNIVERSITY COLLEGE HOSPITAL.

[Wrth Special Plates.]

Ter mechsnical factor discovered by the injection experiments of Menz ${ }^{28-80}$ in 1870 to be the primary cause of papilloedema," choked disc, or "optic neuritis," has been confirmed by many observers, and now most recently by the researches of Cushing and Bordley.

Clinically, my demonstration ${ }^{18-25}$ since 1886 , and especially in 1890, at the International Congress in Berlin, that the mechanical release by trephining in cases of increased intracranial tension due to cerebral tumours, etc. causes the disappearance of "optic neuritis," affords, as I then suggested, the converse proof of the same pathological principle, though Sir William Gowers ${ }^{13}$ has pointed out that, however correct the facts, this inference is not absolute; and, as Sir Henry Swanzy ${ }^{43}$ critically sums up the matter, "a completely satisfactory theory of the causation has not yet been propounded."

Of course, though the mechanical view ought in my opinion to be accepted as established, I have always admitted that, scientifically speaking, we cannot exclude the possibility of other contribating factors existing and co-operating to produce papilloedema. Moreover, according to Elschnig's" view (if $I$ understand him correctly), in the case of papilloedema from brain tumour tho mere swelling or oedema might be regarded as accompanied or not by a neuritis, as the case may be. Thus, in his first figures (Taf. III, Figs. 1 and 2), which I would regard as a beautiful proof of my view that ipsolaterality of tumour and maximal papilloedema is the rule, he regards the more greatly swollen right disc as "oedematous," and the left as in a state of "neuritis optica." In fact, the heading of the case is stated by him as "hemoglioma cerebri " (right occipital lobe), "rechts frische staungs papille, links neuritis optica." He also expresses his position very strongly as follows, ${ }^{6}$ p. 271: "In not a single case does oedema of the optic nerve or of the papilla exist without inflammation." Of course, this depends on what we are to understand by the term "inflammation." The pathological degenerative changes in papilloedema, the histology of which I deal with later, are, I venture to suggest, no correctly termed inflammatory.

Elschnig's view is essentially an expansion of Deutschmann's ${ }^{8}$ original method of regarding the subject, since Deutschmann said, first, that a choked disc is but a higher degree of neuritis.

In the present paper I have no new facts to throw light on this important question of the immediate causation of optic papilloedema, for discussion of which I must refer to Saenger, ${ }^{10}$ to $\mathrm{v}$. Hippel's summary, ${ }^{17}$ and to Thorner's paper immediately following in the same Archiv, but I am anxious to bring forward some considerations respecting the whole process, and particularly on its clinically localizing value, which I believe to be very high.

After 1890, my attention in operating for intracranial disease was directed not only to the obvious need of palliative trephining ${ }_{+}^{+}$(see 18-20) to stop "optic neuritis" and save the sight, but also especially to the further question whether the effects of the raised intracranial

* This term, introduced by Parsons, ${ }^{35}$ has been supported by de Schweinitz 3 as a more scientific appellation of a condition now generally regarded as not truly an inflammatory process.

Cushing and Bordiey in their footnote, p. 86 , seem to have misunderstood my position on this question.

Now conveniently spoken of as decompression. 3 tension was more pronounced, and therefore the intensity of the optic neuritis greater, on the side of the lesion or not. That the neuritis should be probably ipsolateral was suggested to me in a case I published in 1884 . It was not, however, till I had had the experience, after 1886, in operating on a number of tumour cases that I published ${ }^{21}$ in $1895 \mathrm{my}$ view that ipsolaterality of the lesion and neuritis was the rule, and I then for measurements of the swelling, etc., relied on the assistance of my late greatly-regretted colleague, Mr. Marcus Gunn. In 1896 Dr. Middelton Martin ${ }^{32}$ commenced a valuable investigation into the subject of the localizing value of optic neuritis. He examined the facts of a very large number of the patients at the National Hospital, Queen Square, including $m y$ cases, as well as the records of many others from other sources, 600 in all. As regards ipsolaterality he found that of 55 cases in which the relative point was specifically noted the " neuritis" was greater on the side of the lesion in 39 cases-that is, in 71 per cent.

Also Dr. R. T. Williamson ${ }^{47}$ published in 1896 an elaborate study of frontal lesions in which he collected 50 cases from all sources, including the National Hospital for Paralysed and Epileptic. Of these he states that of 35 cases the neuritis was either anilateral or definitely more marked on one side in 7 cases, in 6 of which the marked ocular changes "were on the side of the lesion." It will be seen presently that the three frontal lesions described below as seen by me during the last twelve months falfil this to the letter, and substantiate the practical value of the indication which has also been expressed by Dr. Purves Stewart ${ }^{22}$ in his textbook.

Bruns $^{2}$ in 1898 referred to unilateral neuritis as a symptom which was only important with further accompanying evidence.

The conclusions of Dr. Martin and Dr. Williamson were founded on the degree of swelling, but it always seemed to me that the severity of the intracranial pressure could be judged more precisely by the secondary histological changes in the disc, and therefore I have for a number of years based my estimation of the neuritis more upon these appearances than on the simple amount of swelling.

Such a course was also necessarily dictated in advanced cases by the difference in time and degree of the neuritis in the two eyes, that is, leading to subsidence of one into atrophy while the swelling of the other was rising.

All these points I have dealt with before, and need only refer to my previous publications ${ }^{21-24}$ on this snbject.

I now wish to communicate facts on certain points in the hope of facilitating answers to the practical questions which must be answered in every case, namely, On which side of the head is the operation to be performed, and what will be the amount of recovery or maintenance of sight?

Points for Discussion.

1. The localizing diagnostic value of papilloedema or optic neuritis.

2. The part of the disc which first becomes oedematous as a consequence of increased intracranial tension.

3. Proof of Mr. Marcus Gunn's view of the mechanism whereby the macular or star figure ("stern figur") is produced.

4. The phagocytes of the retina in neuro-retinitis and their origin.

\section{The Localizing Diagnostic Value of Optic} Neuritis.

My view that we have a valuable aid to clinical diagnosis in the fact that the papilloedema begins on the side of a tension lesion, and as a rule is more severe than that on the opposite side, is of course in direct opposition to the brief notice on the point by Deutschmann, who at the end of his well-known tract (p. 67) quotes three cases of uniocular nearitis known to him (curiously enough all from English literature) which, by contradict. ing each other as to ipsolaterality of the tumour and the "neuritis," in his opinion negatived the possibility of framing successfully any theory whereby the phenomena of papilloedema may be explained.

Last year also my general statement made ${ }^{22}$ on the subject at the meeting of the Association at Toronto in 1906 was questioned by my colleague, Mr. Leslie Paton who formulated ${ }^{87-88}$ to the Ophthalmological Society certain 
conclusions from a statistical survey of our cases at the National Hospital for the Paralysed and Epileptic.

As I pointed out in the discussion ${ }^{87}$ of his paper at the Ophthalmological Society, his results were not only vitiated by the well-known error of throwing all clinical cases together, but also by the fact that his conclusions were in the main based on the degree of swelling. This, as I have just stated, is not so instructive as the minuter degenerative changes in the disc, which must be considered as of prior importance, and without the discussion of which in each case with the clinical and the operative or post-mortem findings, statistics are useless.

Mr. Paton's last paper, published in Brain, July, 1909, deals also with our cases at the National Hospital up to the end of the year 1907.

It is a curiously instructive commentary on the fallibility of clinical statistics that Mr. Paton's conclusions are founded on the records of the National Hospital for the Paralysed and Epileptic, among which are some of my own cases, by the detailed examination of which and of my private patients I had previously arrived at the opposite conclusions to which Mr. Paton has now come. But not only is this the case, but also my cases for 1908 at the National Hospital equally contradict Mr. Paton's figures.

All my cases at the Queen Square Hospital have been re. peatedly and carefully examined by my medical colleagues, especially by Mr. Marcus Gunn and Mr. Paton, my ophthalmological colleagues, and by myself. I therefore, since the discussion in April, 1908, have more especially noted my opinion of each case and compared it with that of Mr. Marcus Gunn and Mr. Paton. The result is agreement as to the degree--that is, including age - of the neuritis on the two sides. I have now placed in the following table, in the order of their occurrence, the tumour cases at Queen Square which I have during the past year personally examined and by removing the tumour proved the position of the lesion (I include one simple decompression case, No. 17, for special reasons, vid. infra).

As a fact, also, these cases are of far better value than post-mortem material, since in the latter case the tension condition of the brain at the time of death by no means corresponds to the pressure conditions existing at the date of onset or observation of the neuritis. The necessity of closely considering the intracranial pressure conditions at the varying periods of any case is natarally not dealt with or met by Mr. Paton's statistics. I shall presently recount in some detail one or two cases which specially bear on this point, but may draw attention meanwhile to Cushing and Bordley's researches in this connexion. Thus of their two artificial tumour cases, in the first, in which they had set up general internal hydrocephalus, the papilloedema began contralaterally, while in the second, in which there was no such universal pressure complication as internal hydrocephalus, the ipsolaterality of the papilloedema and the artificial tumour was complete, and remained so till death eighteen days later. As regards their experiments of the injection of fluid into the sabdural space of one side, they say they have "not infrequently seen the oedema of the disc and retina occur first in the opposite eye to be followed later by equal changes in the near eje."

Nothing less could be expected from the Manz method of experimentation they employed-namely, injection of fluids - which, though of the highest importance on the question of the mechanical factor in general, necessarily does not give defined results of localizing value on the subject of laterality. $*$ The experience of the same authors with the clinical evidence offered by growing neoplasms is distinctly in favour of ipsolaterality-namely, 70 per cent. of all cases; while in their series the first swelling was ipsolateral in 80 per cent., and in 72 per cent. the greatest injury resulted to the nerve of the same side.

I now give in brief tabular form a list of the uncomplicated tumour cases in the fortuitous order of their admis. sion to hospital which have been examined during 1908 by Mr. Paton and myself.

* In the discussion on this paper, Dr. Thomson Henderson ${ }^{16}$ pointed out that the intracranial contents were often erroneously regarded as offering the physical conditions of a fluid, whereas the dural falx and tentorium by their resistance prevented general hydrostatic diffusion of pressure; and further, that since he had shown that the intracranial and intraocular pressures corresponded to the same capillary venous pressure ipsolaterality of the effect of raising the former was to be
expected.
Table of Unselected Tumodr Cases under Sir Victor HORSLEY, IN WHICH SITUATION OF LESION WAS DETERMINED BY OPERATION DURING 1908.

(From the National Hospital for the Paralysed and Epileptic, Queen Square.)

Extracts from Hospital Notes.

\begin{tabular}{|c|c|c|c|}
\hline No. & $\begin{array}{c}\text { Date of } \\
\text { Admission or } \\
\text { Date of } \\
\text { Operation. }\end{array}$ & Lesion. & $\begin{array}{l}\text { Remarks on the Relation of the } \\
\text { Papilloedema to the Lesion. }\end{array}$ \\
\hline 1 & $\begin{array}{l}\text { Nov. 15, 1907 } \\
\text { (operation. } \\
\text { Feb. 18, 1908) }\end{array}$ & $\begin{array}{l}\text { Left } \text { Rolandic } \\
\text { area tumour }\end{array}$ & $\begin{array}{l}\text { Indeterminate. Mr. Gunn's } \\
\text { note: R.+3. L.+2.5 Tiny } \\
\text { haemorrhage noted in right } \\
\text { eye. Mr. Paton's note : }\end{array}$ \\
\hline 2 & Feb. 10, 1908 & $\underset{\text { tumour }}{\text { Right }}$ frontal & $\begin{array}{l}\text { Ipsolaterai. Right: Very in- } \\
\text { tense neuritis with haemor- } \\
\text { rhages and white exudate. } \\
\text { Left : No haemorrhages and } \\
\text { less exudation. Day before } \\
\text { operation left swelling became } \\
\text { equal to right, and possibly } \\
\text { more. Diagnosis of sile of } \\
\text { lesion based wholly on the } \\
\text { neuritis in this case. }\end{array}$ \\
\hline 3 & $\begin{array}{l}\text { Feb. 18, } 1908 \\
\text { (operation) }\end{array}$ & $\begin{array}{l}\text { Right subcortical } \\
\text { Rolandic tumour }\end{array}$ & 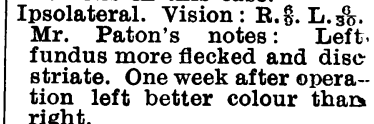 \\
\hline 4 & Mar. 9, 1908 & Left & Ipsolateral. L. + 6. R.5.5. \\
\hline 5 & April 21, 1908 & $\begin{array}{r}\text { Left eighth nerve } \\
\text { extra-cerebellar } \\
\text { tumour }\end{array}$ & 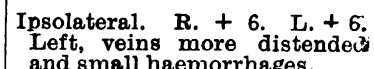 \\
\hline 6 & May 4, 1908 . & $\mid \begin{array}{c}\text { Left } \\
\text { bellar tumour }\end{array}$ & Ipsolateral. L. +6. R. +5. \\
\hline 7 & May 25, 1908 & $\begin{array}{l}\text { Left temporo- } \\
\text { sphenoidal } \\
\text { tumour }\end{array}$ & $\underset{\text { fieuritis older in left. }}{\text { Ipsolateral. }} \mathbf{\text { L. }}+\mathbf{7}$ \\
\hline 8 & May 29, 1908 & $\begin{array}{l}\text { Right frontal } \\
\text { abscess }\end{array}$ & $\begin{array}{l}\text { Ipsolateral. R. + 1.5. L. no } \\
\text { neuritis. Papilloedema grad- } \\
\text { ually developed in left eye. } \\
\text { Patient comatose and impoos- } \\
\text { sible to obtain localizing } \\
\text { symptoms as to size of lesion } \\
\text { except by the neuritis. }\end{array}$ \\
\hline 9 & June 15, 1908 & $\begin{array}{c}\text { Right temporo- } \\
\text { spheno oid a } \\
\text { tumour }\end{array}$ & $\begin{array}{l}\text { Ipsolateral. R. }+8 . \text { L. }+7 \\
\text { Neuritis more }+7 \text { intense right } \\
\text { than left. }\end{array}$ \\
\hline 10 & June 26, 1908 & $\begin{array}{l}\text { Right Rolandic } \\
\text { tumour }\end{array}$ & $\begin{array}{l}\text { Probably ipsolateral. Notes } \\
\text { not full. Mr. Gunn's note: } \\
\text { Globes unsteady. R. + } 5 . \\
\text { High colour. Edges invisible. } \\
\text { L. + 5.5. Physiological pii } \\
\text { not flled. }\end{array}$ \\
\hline 11 & Sept. 14, 1908 & $\begin{array}{l}\text { Right and mid- } \\
\text { line frontal } \\
\text { tumourpressing } \\
\text { on left optic } \\
\text { nerve }\end{array}$ & 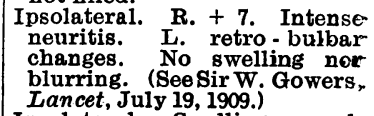 \\
\hline 12 & Sept. 28, 1908 & $\begin{array}{l}\text { Right temporo- } \\
\text { sphenoidal cere- } \\
\text { britis }\end{array}$ & $\begin{array}{l}\text { Ipsolateral Swelling equal. } \\
\text { Changes in right disc older } \\
\text { than those in left. }\end{array}$ \\
\hline 13 & Oct. 10, 1908 & $\begin{array}{c}\text { Right ponto-cere- } \\
\text { bellar tumour }\end{array}$ & 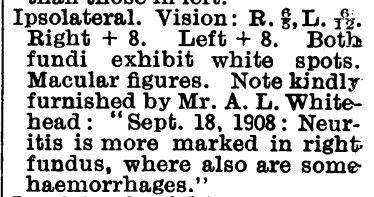 \\
\hline 14 & Feb. 12, 1909 & $\begin{array}{c}\text { Right fronto- } \\
\text { parietal tumour }\end{array}$ & $\begin{array}{l}\text { Ipsolateral. Right }+3 \text {. Left } 2.5 \text {. } \\
\text { Haziness and blurring, and } \\
\text { converging of vessels more } \\
\text { marked on theright. Haemor- } \\
\text { rhages appeared right before } \\
\text { left, and more marked. } \\
\text { Vision o bothe eyes. Right. } \\
\text { disc became whiter earlier } \\
\text { than left. }\end{array}$ \\
\hline 15 & Mar. 3, 1909 & $\begin{array}{l}\text { Left cerebro-pon- } \\
\text { tine tumour in- } \\
\text { volving mid- } \\
\text { line. Limits not } \\
\text { determined at } \\
\text { operation }\end{array}$ & $\begin{array}{l}\text { Ipsolateral. Left }+4 \text {. Right }+3 \text {. } \\
\text { Left oedema wider spread anà } \\
\text { redder than right. }\end{array}$ \\
\hline 16 & Mar. 26, 1909 & $\begin{array}{c}\text { Left Rolandic } \\
\text { area tumour }\end{array}$ & $\begin{array}{l}\text { Ipsolateral. Left }+3 \text {. Right }+2 . \\
\text { Left edge of disc blurred } \\
\text { right ditto, but perceptible. } \\
\text { Diffuse haemorrhage left } \\
\text { none rieht. Left swelling } \\
\text { steeper than right. }\end{array}$ \\
\hline 17 & May 7, 1909 & $\begin{array}{l}\text { Parieto - tem- } \\
\text { poral. ? Left } \\
\text { s u b c or ti c c al } \\
\text { tumour. Decom- } \\
\text { pression opera- } \\
\text { tion, tumour not } \\
\text { seen }\end{array}$ & $\begin{array}{l}\text { ? Contralatera. Papilloedema } \\
\text { began under observation in } \\
\text { the right fundus : always } \\
\text { more intense right than left. } \\
\text { May 17, 1909: R. + 3, few } \\
\text { haemorrhages; L. }+2 \text {, no } \\
\text { haemorrhages. }\end{array}$ \\
\hline 18 & June 17, 1909 & $\begin{array}{l}\text { Left eighth nerve } \\
\text { extra-cerebellar } \\
\text { tumour }\end{array}$ & $\begin{array}{l}\text { Ipsolateral. Left papilloedema. } \\
\text { moltitled white and extending } \\
\text { further into retina than on } \\
\text { right side. L.+5. R.+4. } \\
\text { Large haemorrhage in left, } \\
\text { tiny ditto in right. }\end{array}$ \\
\hline
\end{tabular}


The table speaks for itself, and the results are simply in my opinion typical of the condition, namely, that ipsolaterality of the tumour and the nouritis is the rule, and that contralaterality is the rare exception. The only case, indeed, of apparent contralaterality which occurred among my hospital cases during the joar is the decompression case No. 17. I include it because everything pointed clinically to the diagnosis being accurate, but the tumour was not seen at the operation, and therefore even this case remains uncertain. Before examining further into this question of contralaterality I wish to draw attention to the fact that among even these unselected 18 cases, in no less than 2 the correctness of the localization diagnosis depended wholly on the degree of the neuritis. If the responsibility of the surgeon can be thus relieved on the all-important question as to which side of the head he is going to open, what better demonstration of the truth of my clinical position can be offered?

To the facts in the table I desire to add the histories of three cases from my private practice during the past year, not only because they bear directly on the question of contralaterality, but because they illustrate my conten. tion that any discussion of papilloedema to be profitable must include a detailed consideration of the clinical features in each case.

Case $I$.

The first case, which had been referred to me as an " unusual case of general paralysis accompanied by optic neuritis," had been under observation for a long time, consequently the patient was already blind in one eye. When I examined him I found a highly intelligent man, presenting relative absence of psychical initiation, loss of memory, loss (both nostrils equally) of intellectual appreciation and determination of odours, but absolutely no other symptom. There was consequently no means of localizing the side of the lesion, except by the degree of neuritis. I found the character of the neuritis in the two eyes to be :

Right : Opal-glass-like* swelling of disc.

Left : White spots over oedematous disc.

Vision.-Right: No perception of light. Left : Reads easily small print with correction.

Mr. Harold Grimsdale examined and very kindly reported the case as follows :

Vision.-Central acuity. Right: No P.L. Left: $\frac{8}{6} \mathrm{~N}$. with correction. Swelling.-Right: +3 (was +4 four months ago). Left: Higher than before.

A copy of Mr. Grimsdale's perimetric chart of the left field is given further on (Fig. 24).

Thus the papilloedema of the right side was subsiding into extreme atrophy, while that of the left was in full development. On the evidence of the neuritis, I made finally the diagnosis of a frontal tumour on the right side, and removed from the right frontal lobe a very large endothelioma which also sent a small tongue of growth around the falx into the left side, thus pressing on both olfactory tracts and bulbs.

Case II.

Another interesting case which exhibited apparent contralaterality I will now briefly detail, as it exemplifies extremely well the futility of quoting one clinical feature - for example, the papilloedema - of a case without regard to other concurrent conditions or the changes in the circumstances of a case especially as regards the intracranial pressure.

The patient was seen by one of my colleagues, who diagnosed cerebral tumour. No neuritis was then present. Within four days, when I first saw the patient, paresis of the right third and sixth nerves developed and papilloedema commenced-right +3.5 , left +1.5 -the oedema changes being distinctly more marked on the right side. The other clinical symptoms also pointed to the right hemisphere being the seat of severest pressure. The patient was extremely staporous, and this suddenly deepened early in the morning on the day on which a right temporal decompression was performed. The coma was not relieved, but deepened still further, and terminated fatally in three days. The papilloedema had greatly developed with haemorrhages, and, as will be seen

*A term I use to indicate the intensely atrophic appearance of a growing tumours, and in which papilloedema has lasted many months. in the photographs Figs. 3 and 4, the change was now most severe in the left fundus. The explanation of this reversal was furnished by the autopsy.

As is shown in Fig. 8, the tumour was originally really in the left frontal lobe close to the mid-line, but exerting its most severe pressure downwards on the right hemisphere through the corpus callosum and the anterior third of the ventricle to the base. Farther, as shown in Fig. 7, the growth also infiltrated both sides of the mesencephalon, and caused, in addition to other focal haemorrhages, one very precisely limited to the nucleus of the right third nerve.

Thus the greater incidence of the papilloedema and peripheral nerve paralyses on the right side was accounted for. Finally, the cause of the sudden increase of pressure and of the greater development of the left papilloedema during the last few days of life was found to be due to an extensive haemorrhage from the surface of the tumour through the superior frontal gyrus and spreading all over the left hemisphere. The intensity of the papilloedema thus varied directly with the side of greatest pressure.

\section{Case III.}

I also desire to give briefly the facts of a third case to show how reliable the papilloedema is among the other clinical symptoms and how it can sometimes afford better guidance than equivocal nerve phenomena.

It was that of a science student who after three indeterminate epileptic fits had become stuporose. The difficulty of examining him was great, but he presented very markedly symptoms of pressure on the right cere. bellar peduncle, and occasionally according to his friends speech difficulty (? paraphasia). The papilloedema was most intense, as shown in the photographs of the fundi (see Figs. 1 and 2), on the left side. As the level of pressure was clearly tentorial I decided to make the decompression opening (for no more could be attempted) in the right cerebellar fossa to obtain the maximal drainage.

He succumbed, however, to shock, and at the autopsy it was found that, as shown in Fig. 14, he was suffering from a cystic tumour of the left temporal lobe at the incisura occipito-temporalis, which caused severe dis tortion of both halves of the mesencephalon and optic thalamus.

If the nerve symptoms had been ignored and the decompression made (as the neuritis suggested) over the left temporal lobe, it is probable that the fatal termination of the case might have been postponed and the chance, however small, of removing the lesion given to the patient.

In this case, therefore, the degree of the neuritis and secondary changes in the fundus were of the first importance in the clinical condition and care of the patient.

The photographs of the fundi in the foregoing cases show that the occurrence and development of haemor. rhages is also of notable importance in estimating the degree of papilloedema. In holding this view also I am sorry to find myself in conflict with Mr. Paton's figures (compare also Figs. 5 and 6).

I need not multiply such cases, but they will serve to support my contention that when a case of apparent contralaterality of tumour and papilloedema occurs the pressure conditions of the case must be most carefully reconsidered from every possible point of view to avoid error, for my experience, at any rate, goes to show that where the details of clinical observation are collated the safest guide to follow is the papilloedema. I have little doubt that, provided the circumstances of the intracranial tension at different times in the evolution of the case are adequately inquired into, all apparent anomalies and contradictions of the ipsolaterality rule I have suggested will diminish and ultimately disappear.

\section{The Part of the Disc which becomes Oedematous.}

Following on the suggestion I made three years ago that the papilloedema always begins at the upper nasal quadrant of the papilla, and not, as has also been suggested, its lower border, further observation has convinced me that this is the rale, and therefore that in suspicious cases the changes in this region of the disc must be carefully and constantly watched. On this point I have this year had the special opportunity of examining post mortem two early cases of neuritis. 
On removal * of the eyes in both cases it was noticeable that the retrobulbar ampulla was in both cases most marked on the dorsum of the nerves. This is well shown in the photograph (Fig. 9) of such an eye in profile, and on section (see Fig. 10) the sheath is seen to be most distended in its dorsal region. A converse proof of the same fact is afforded by Mr. Grimsdale's accompanying perimeter chart of the left field (Fig. 24) in Case I detailed above. It will be seen that the contraction of the field is most marked in its lower border. Such a result t will probably be only found in severe cases (compare the charts of simpler cases published by Dr. Charles ${ }^{4}$ ), a good example of which is the chart, Fig. 67 of Mr. Adams Frost's ${ }^{12}$ beautiful atlas.

Probably a simple structural explanation of this exists; but whatever this may prove to be, the anatomical fact is, I believe, constant. Quite recently my view has also been confirmed by the experiments of Cushing and Bordley. The two successful cases by these observers, ${ }^{20}{ }^{21}$ in which they introduced sponge tent as a source of elastic com pression, are those I would refer to. Even in the first (in which hydrocephalus was also set up) the right eye (contralateral) began first to exhibit choked disc appearances in " the upper part," the left following later.

That, as regards the lateral halves of the disc, the nouritic swelling should be greater on the nasal side was originally discussed in 1879 by Kuhnt, who showed that the specially loose connective tissue lying under the disc in front and to the outer side of the choroidal aperture, forming a transition element between the highly organized tissue of the retins and the connective tissue of the perineurium, was greatly developed on the nasal side and less on the macular side Consequently the disc rises more on the nasal side in proportion as this "intermodiary tissue," as Kuhnt called it, becomes tumefied and constitutes the "Wulst" of German authors.

Sir.William Gowers has pointed out for many years that the greater mass of nerve fibres of the inner half must afford more scope for the occurrence of greater oedema swelling on the nasal side. The accompanying photographs (Figs. 3 and 4) show not only this, but also, what is of greater practical importance, that the white degeneration spots commence on the nasal side of the disc at the point of greatest tension, namely, the edge of the glacis of the elevation-that is, just beyond the projected border of the normal disc. The spread of the oedema, therefore, is from the top down the nasal half first, and later the temporal half. Consequently the lower outer quadrant is the last to be obscured (Figs 5 and 6). Conversely I have often watched a disc clear in the opposite order.

In reference to this question of the localization in the disc of the initial changes, especially in considering their mechanical "causation, it is necessary to keep in mind the fact that a toxic papilloedema-for example, produced experimentally in animals by extract of filix mas-

* In all cases I fix the intact eyeball and nerve in 10 per cent. formalin solution, marking the sides and retaining the tendon of the superior rectus. Within two to five days an equatorial section of the globe is ads the superior is thus facilited ( photography is thus facilitated.) During the section the bulb is held Ty the nerve so that some vitreous remains in the cup of the fundus. ime specimen is then at once lowered into water and photographed immediately, the camera being inverted and suspended over the Beck-Steinheil anastigmat $f=3.5^{\prime \prime}$ and an elongated camers.

+ I have since the meeting observed the same loss in the field in a similar case

$\ddagger$ Possibly the development of the elastic fibres in the nerve sheath, and to which. $\nabla$. Kriudener has specially drawn attention, may be greater on one aspect of the sheath than the other. evokes a swelling of the papilla, according to Nuel ${ }^{38}$ presenting for a fortnight or more "absolutely the appearance of a papilla in typical stasis" (loc. cit., p. 18)that is, choked disc, without producing distension of the sheath. In this connexion Nuel also refers to Parinaud's contention that the distension of the sheath and produc. tion of the ampulla is not the prime cause of papilloedema from intracranial conditions. ${ }^{34}$

Distension of the sheath, therefore, is a secondary phenomenon, whatever the cause of a papilloedema may be. In this connexion it is interesting to note that the effects of a local injury to the sheath and vessels of the optic nerve may be more pronounced in the nasal half of the choroid and retina (see Plate $X$, published 1869 by Hermann Pagenstecher).

\section{Proof of Mr. Marcus Gunn's Interpretation of} the Production of the Macular Figure.

The fan-shaped radiation in the macular region, and especially between the macula and the neighbouring. margin of the disc, so far as the production of its beantifully regular arrangement by oedema has been especially discussed by Mr. Marcus Gunn, ${ }^{14} 15$ who in 1894, at the International Ophthalmic Congress (Edinburgh), drew atten tion to the localized foldings of the retina that occur in consequence of oedema and of what he described as "the pegging-down of the forea centralis " compared to other regions of the retina. He suggested, therefore, that mechanical tension plus degenerative processes in the retina accounted for the figure. In his discussion of the perfection of the pattern, Mr. Gunn pointed out truly that any radial arrangements of Müller's fibres cannot be properly invoked in explanation. The question thus raised is an interesting one, and is associated with the further question of the normal conditions, especially the so-called plica centralis. Hannover said : "The so-called plica centralis. does not exist in the human eye," and from his time to that of Ginsberg. it has gradually been recognized that this is true. But the scientific demonstration of the fact has now been established by the exquisite photographs of the living fundus by Dimmer.9 ${ }^{10}$ (See especially the strik. ing figures of Plate VIII of his monograph.) It is as a consequence of post-mortem change that the macular region tends to be raised in a ridged form, the long axis of which is directed horizontally towards the disc. This is well shown in the figures (Figs. 1-6). This folding is practically constant in eyes even when fixed very soon after death. In the monkey the retina also exhibits folds at exactly right angles to the ridge just mentioned, so that the fovea is the central axis of a Latin cross. The same figure may be often seen post mortem in the humen eye. Conceivably, then, innumerable radiating lines from the maeula may be drawn between these transverse axes, and thus the star figure produced. It occurred to me that this might be tested by artificially altering the physical tension in a case of slight papilloedema. I, therefore, in an eye from a case of early optic neuritis, having fxed the fundus not only with formalin and osmic acid, but afterwards with absolute alcohol, exposed the preparation to drying, so as to obtain tension effects. During life no macular figure was present nor any folds observable ophthalmoscopically, but as the drying proceeded the retina began to crinkle in a star-shaped pattern, the centre of which was the forea. Microscopically, the intima was seen to be raised, or in other words, the effect of the tension makes itself felt first in the nerve fibre layer (see Fig. 21). This last point is important, because there evidently exists 
some confusion as regards the anatomy of the white spots in the macular figure and their localization according as to whether the changes in the fundus are due to cerebral tumour or albuminuric toxaemia.

Mr. Gunn, for instance, spoke as though the white spots are necessarily due to changes in the deeper layers of the retina, as in albuminuric retinitis. But both ophthalmoscopically and experimentally it is clear that the white spots, whether on the disc itself or around the macula in cerebral tumour, are in the nerve fibre layer. Since they are the most important of the secondary histological shanges of value in estimating the degree and effects of neuritis, I have, in order to estimate better their degree and development, devoted some time to their study and will now discass their formation under the more general question of the phagocytes of the retina. $A s$ being the direct eonsequence of the destructive influence of the sedema on the nerve fibres and tissue of the retina the spots necessarily occur first near the vessels, but particularly on the nasal half of the disc as stated above. This is specially well shown in the early neuritis photo.graphed in Figs. 1 and 2, where they are dotted round the nasal border of the disc almost solely.

4. The Phagocytes of the Retina.

Excepting the ubiquitous wandering leucocytes, the - origin of phagocytes and macrocytes in inflammatory foci in the nervous system has always been a muchcontested matter from the time of Gluge to the most recent work by Fritz Marchand, jun. ${ }^{31}$ As regards the central nervous system, Clarke and myself have drawn attention to the variations in these cells as occurring in - electrolytic lesions. In the retina, however, as I interpret the descriptions given by the textbooks, the question is somewhat complicated by the formation of cell.like bodies which have been regarded from the time of $H$. Miuller as "varicose nerve fibrils," though correctly described as lying in the nerve fibre layer around the bases of Müller's fibres. If I have seen the same structures, then I suggest that the current terminology is not justified (certainly they do not resemble varicose nerve fibres in any other part of the body), and that they ought to be regarded as macrocytes originating from endothelial cells normally lying upon Müller's fibres.

On studying the question in early cases of papilloedema, or choked disc, and comparing the preparations with sections from the fundus of an extreme case of albuminuric retinitis (see Fig. 13) kindly given me by Dr. Janet LaneClaypon, it seemed clear that, apart from wander-cells (chiefly in cone layer, see.Fig. 16), there are three kinds of phagocytes to be considered in the retina, of which the first two are found in the nerve fibre layer in the classical position described-namely, around the bases of Müller's fibres; and the third are the well-known singularly large cells found in the outer granule layer between the stretched and separated processes of the retinal elements and cemains of the radial fibres.

(a) Phagocytes of the Nerve Fibre Layer.

These are the most interesting because by their aggregation and contents of fatty material they constitute the white spots on the disc in papilloedema. As typical specimens sections are shown in the accompanying photographs (Figs. 11 and 12) taken from a series made through the nasal half of the disc shown in photograph (Fig. 1).

Fig. 12 shows that the white spot consists of an opal swelling which, besides a few (1) red blood corpuscles, is principally made up of (2) masses of macrocytes, which, anstained or stained with nuclear dyes, usually exhibit in their centre a large nucleus as figured by Greeff. These macrecytes of the nerve fibre layer, however, do not take up any of the myelinic débris from the nerve fibres. They are "epithelioid "cells, and resemble those described by Nuel as arising in the softened foci of the optic nerve trunk when affected by a toxic neuritis. Stained with osmic acid they remain with clear homogeneous protoplasm, quite different to the analogous macrocytes of the outer granule layer, and in sharp contrast to the smaller blackstained corpuscles immediately to be described.

These (3), the third class of constituents of the white spot, are the phagocytes, to which its colour is really duethat is, those which contain the fatty débris. These cells, it is interesting to note, are of a totally different class; they are not wandering leucocytes, but obviously connective tissue corpuscles, and, in sections stained with osmic acid, are filled with black granules. They have the usual stellate or elongated, flattened, and branching bodies of typical connective tissue corpuscles (see Fig. 22). They lie between and among the oval macrocytes just mentioned (see Fig. 12). They do not appear to take up blood pigment from the haemor. rhages, but so far I have not examined any long. standing case from this point of view. To judge from other parts of the body, this duty of absorbing free pigment granules is effected by wander.cells, and certainly, when the retinal pigment cell layer is separated by exudate, leucocytes containing pigment granules can always be found (see Fig. 20). I was much surprised to find in such a highly organized nerve structure as the retina phagocytes resembling true connective tissue corpuscles, but perhaps this is to be attributed to its finally being an ultimate part of the peripheral system. The coexistence of proliferative endothelial cells is, of course, easy to understand.

A further point of interest is that in Kubnt's "intermediate tiesue" of the disc such connective tissue phagocytes lie grouped along the blood vessels, and thus occur scattered throughout the whole depth of the disc. They occur here in albuminuric neuritis as well as in tumour papilloedema cases. In the photograph (Fig. 15) of the disc in the albuminuric case the osmic-stained section shows well the base of a white spot, and that the blackened fat-containing phagocytes lie on its surfacethat is, in the nerve fibre layer between the haemorrhagic exudate and the intima.

(b) Phagocytes of the Outer Granule Layer.

In examining the retina in the very early but marked case of papilloedema shown in Fig. 3, I found that the inner segment of the outer granule layer had already become oedematous. Between the cell processes, separated as Iwanoff ${ }^{26}$ originally described, lay a certain number of relatively large corpuscles adherent to Müller's iibres, and apparently of an epithelioid type (see photomicrograph). These cells are, I believe, the same as those which develop into the large phagocytes in this region in such large numbers in albuminuric retinitis (Figs. 16, 17, 18, 19). It is, of course, impossible to furnish strict proof of a statement of this kind, but by following degrees of the degenerative changes it seems justifiable to make such a conclusion. In simple papilloedema the cells in question show a very definite small nucleus near the periphery of the cell, and a body containing a finely granular protoplasm. In albuminuric retinitis the smallest of these cells contains some black granules after staining with osmic acid (Fig. 23). Among such granular cells others may be found in which the body of the cell is occupied by colloidal-looking material which stains light-brown with. osmic acid, and intensely, with iron haema. toxylin (see Fig. 18), as well as with polychrome methylene blue, and is obviously of a proteid nature. As this material increases in the phagocytes the nucleus shrinks, is gradually pushed to the side of the cell, and finally extruded. There finally remains, therefore, a large spherical mass (Fig. 16) very often only barely showing that it is an aggregation of droplets. The origin of these amorphous-looking bodies has given rise to some discussion, but a series of sections through the neighbouring parts of the retina in any given case reveals so many stages as to sufficiently indicate their true origin from the epithelioid cells.

These large phagocytes lie in the oedema spaces artificially formed by the dissociation and destructive separation of the processes of the outer granules and the radial fibres.

SUMmary.

1. The maximal intensity and age of the papilloedema or optic neuritis in cases of increased intracranial tension is of the highest value in clinical localization of the lesion, and is ipsolateral with the maximal pressure effects of the latter.

2. Papilloedema produced by increased intracranial tension commences at the upper border of the optic papilla, and invades last the inferior temporal quadrant. 
3. The macular figure, as Mr. Gunn stated, is caused by tension lines centred at the fovea, the greatest stress being just beneath the intima.

4. The phagocytes of the retina consist of several kinds, as follows: (1) Wander-cells; ( (2) connective tissue corpuscles; (3) epitheloid corpuscles of the nerve fibre layer; (4) epithelioid corpuscles of the outer granule layer-the two latter varieties being in close relation to the supporting fibres of Müller.

REFERENCES

1 Babinski et Chaillous : Société Française d'Ophtalmologie, 1907.

2 Bruns : Neurologisches Centralblatt, 1898, 8. 781-2.

3 Chaillous : Recueil d'Ophtalmologie, 1908, T. 30, p. 291.

4 Charles: American Journal of Ophthalmology, 1909, vol. xxvi, p. 161 5 Cushing and Bordley: Bulletin of the Johns Hopkins Hospital, 1909 , vol. $\mathrm{xx}$, p. 95 .

Cushing and Bordley : Transactions of the American Medical Association, vol. lii, p. 353 .

De Schweinitz and Holloway: The Operative Treatment of Papill dema, The Transactions of the College of Physicians of Philadelphia, 1908, vol. Xxx, p. 140

(insesonderes die sogenannte gungspapille, etc. Jena, 1887.

9 Dimmer: Archiv fiir Ophthalmologie, 1907, Bd. 65, S. 544

10 Dimmer

11 Elschnig : Archiv für Ophthalmologie, 1895, Bd. 41, Abth. 2, p. 179. Wiener klinische Rundschau, 1905, No.

12 Frost, Adams: The Fundus Oculi, etc. 1896.

18 Gowers: Lancet, July 10th, 1909 .

14 Gunn: BRITISH MEDICAL JodRNAL, 1907, p. 1126.

15 Gunn: Transactions of the Internatijnal Ophthalmic Congress (Edinburgh) 1894

16 Henderson (Thomson): British Medical Jodrnal, 1909, vol. ii,

p. 878 .

17 v. Hippel : Archiv für Ophthalmolngie, 1908, Bd. 69, Heft 2, p. 290

18 Horsley: Le Mercredi Médical, August 27th, 1890, p. 415.

19 Horsley: British MedTCAL JouRNAL, 3890, vol. ii, p. 1286.

20 Horsley : Ibid., 1893, December 23rd, p. 1366.

21 Horsley: Clinical Journal, February 13th, 1895.

22 Horsley : BrITISH MEDICAI, JoURNAL, 1906, p. 412.

23 Horsley : Transactions of the Ophthalmological Society of the United

Kingdom, 1908, vol. Xxviii, p. 136

Horsley: Ophthalmosccpe, 1908, September.

25 Horsley: BRITISH Medical JodkNAL, 1909, September 25th, p. 877.

(Abstract of present paper.)

26 Iwanoff : Archiv tiir Ophthalmologie, Band 15, Abth. 2, S. 88.

27 . Krüdener : A rchiv fiir Ophthalmologie, 1907, Bd. 65, S. 69.

(16, S. 265 . Bd.

(29 Merigina)

paper).

80 Manz : Archiv fiir Psychiatrie. 1889, Bd. 20, S. 567.

31 Marchand, F., jun. : Ziegler's Beiträge, 1909.

Martin, Middelton: The Localizing Value of Optic Neuritis in

${ }_{88}$ Nuel : Les névrites optiques. Le Névraxe, 1901, vol. iii, p. 1.
${ }^{8}$.

34 Parinaud: Etude sur la Névrite Optique. Paris: Baillière et Fils. 1877.

35 Parsons: Pathology of the Eye, 1908, vol. iv, p. 1249 et seq.

36 Paton: Transactions of the Ophthalmological Society of the United Kingdom, 1905, vol. Xxv.

${ }^{37}$ Paton: Ibjd., 1908, vol. xxviii (this paper is of cases observed in the National Hospital during 1906-71

88 Paton: Brain, 1908, (No. 22 much extended and reprinted with dditional tables)

${ }^{89}$ Rowlands: Guy's Hospital Gazette, 1898, Nov. 5, and Medical Press, 1909 , p. 14.

Saenger. For full list of papers on the subject see v. Hippel's paper, p. 353 .

41 Schmidt: Archiv für Ophthalmologie. Bd. 15, Abth. 2, S. 193

42 Stewart, Purves: The Diagnosis of Nervous Diseases, 1908, p. 414 419.

Swanzy : Eye Diseases and Eye Symptoms in their Relations to

vol. iv, p. 539. . 189.

Archiv für Ophthalmologie, 1909, Band 69, Heft 3, S. 391

Wilbrand u. Saenger: Neurologie des Auges, Bd. 4, pp. 310-322.

47 Williamson : Brain, 1896, vol. xix, p. 346

\section{MINER'S NYSTAGMUS.*}

By T. HARRISON BUTLER, M.D.OxoN. HONORART OPHTHALMIC SURGEON TO THE COVENTRY AND WARWICKSHIRE HOSPITAL.

IN all colliery centres miner's nystagmus is a very common disease. It is scheduled under the Act of 1907 as a condition for which a miner may claim compensa. tion, and so a knowledge of its leading characteristics is essential to all medical men practising in such a district. The average ophthalmic textbook devotes only a few lines to the affection, and even the meagre information given is apt to be somewhat dogmatic and inaccurate.

The symptoms in a severe case are very characteristic. The eyes oscillate violently, the eyelids twitch, and the man appears to be, and often is, in a state of great nervous agitation. When his visual acuity is tested with the types

* Read t: the Coventry Division of the British Medical Association. it will generally be found to be as low as one-tenth of the normal. He is quite unable to read or to continue at his work, and will frequently complain that he cannot see his way about in the dark. But such a violent attack is uncommon, and it will be, therefore, proper to consider in detail the more usual manifestations of the affection.

The history is typical. The miner has almost invariably worked some years in the pit, and has in most cases been a "holer," one who lies on his side and undercuts the seam of coal. He first notices that at the end of a day's work the lights begin to "dance." They may dance vertically, horizontally, or in a circular fashion like a Catherine-wheel. He can for a time overcome this oscillation by looking down and resting his eyes. Soon, however, the dancing commences earlier in the day, and he more frequently has to "steady" his eyes, and finally the lights begin to dance as soon as he enters the mine, and work becomes impossible. At this period the subjective sense of movement may cause vertigo.

In the early stages of miner's nystagmus the sufferer is free from trouble when he leaves the pit, but as the disease progresses nystagmus is present when it grows dark and the street lamps are lighted. Eventually nystagmus is always noticed, even in daylight.

At the beginning of the case nystagmus only commences when the eyes are considerably raised, then it appears as soon as the gaze rises above the normal plane, and later it only ceases when the sobject looks down. In fact, the severity of the attack can be accurately gauged by the angle above or below the primary position at which nystagmus can be elicited. The position of the head, however, has notbing whatever to do with the matter; nystagmus can be demonstrated just as easily in the supine posture if the eyes be directed towards the brows as it can in the erect. Peters is quite incorrect when he states that nystagmus ceases if the head be thrown back. It does so in many cases if the patient looks at the same object, but if he move his eyes back pari passu with his head nystagmus does not cease.

In a slight case, or one which is in process of cure, it may often be impossible to detect any nystagmus by. simply raising the eyes. Reid has taught us that if we rotate the patient several times, until he is a little giddy, and then direct his eyes to the ceiling, nystagmus may appear. If we can produce no nystagmus by this method it is safe to assume, either that the case is not one of nystagmus, or that it has been cured.

The direction of the nystagmus may be vertical, horizontal, or circular. In my own practice the vertical variety has been rare. One eye may have a different kind of nystagmus from the other.

Hemeralopia may be present. Court found it in 127. cases out of 164 ; Dransart detected it in 5 per cent. of his patients. Romiée states that he has never seen this symptom, although he has examined several thousand individuals. My own experience has been that night blindness is undoubtedly a symptom of the disease. Probably. at least 25 per cent. of all cases are unable to see in the dusk.

Visual acuity is unaffected when the eyes are at rest. If the types be placed on the floor level and the miner stand upon a chair, he may read the last line; if he sit down and the types be hung on the wall, he may fail to read the top line.

I shall now present my case to you :

T. R., aged 45, was a miner in the Newãigate Colliery, a lamp mine; had been a miner all his life.

About six months ago he began to notice that the lamps were dancing up and down. He had to sit down and "steady" his eyes. Three months ago, when he was examining the roof, a piece of coal fell upon his nose and cut his face. Had he nos had violent nystagmus he would have seen that a large fragment was loose and would have avoided it. After the accident the nystagmus got much worse. He sees very badly at night, not only becanse everything is in motion, but because there is a " sort of mist before his ezes." He sees a little better if he looks down, but not so well as his mates do. In fact, he has slight hemeralopia.

Condition when First Seen.-Violent nystagmus and twitching of lids. Vision $=\frac{8}{80}$. Advised to give up his work underground entirely and permanently.

Condition a Month Later. -The eyes were normally at rest, but if he looked at an object fxedly for a few seconds his eyelids began to blink and twitch violently and he looked away as though shielding his eyes from a dazzling electric arc. As soon 


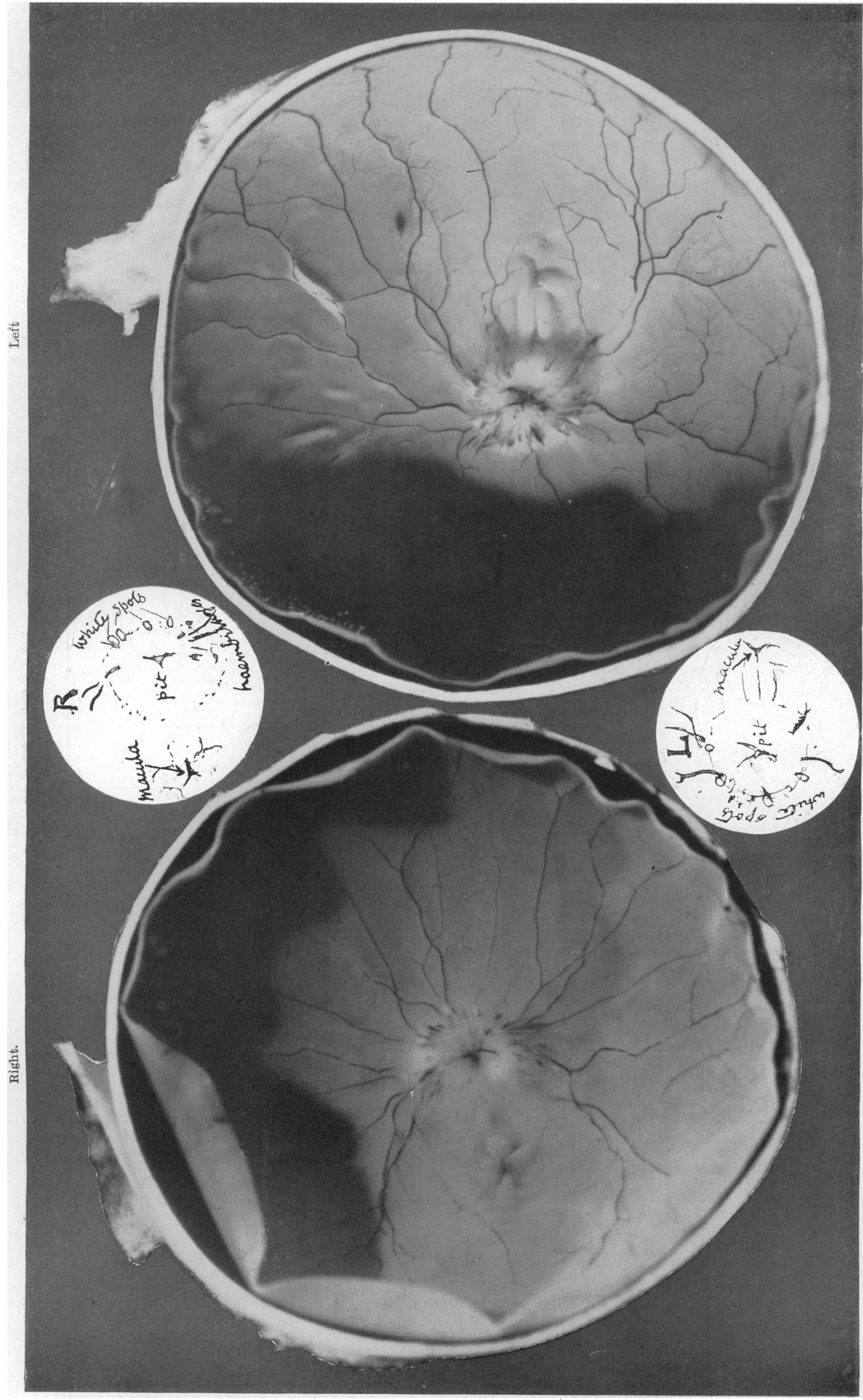




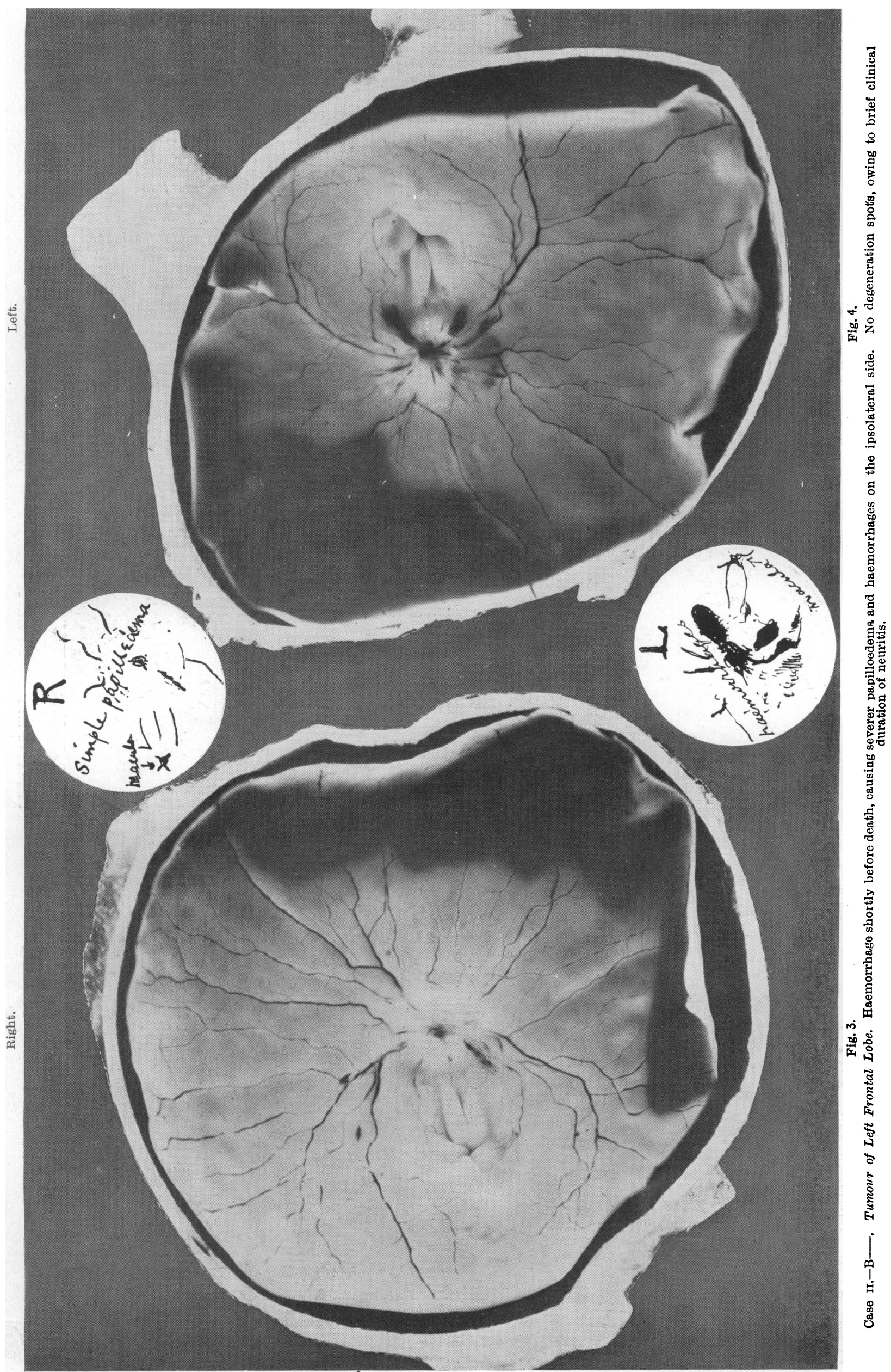




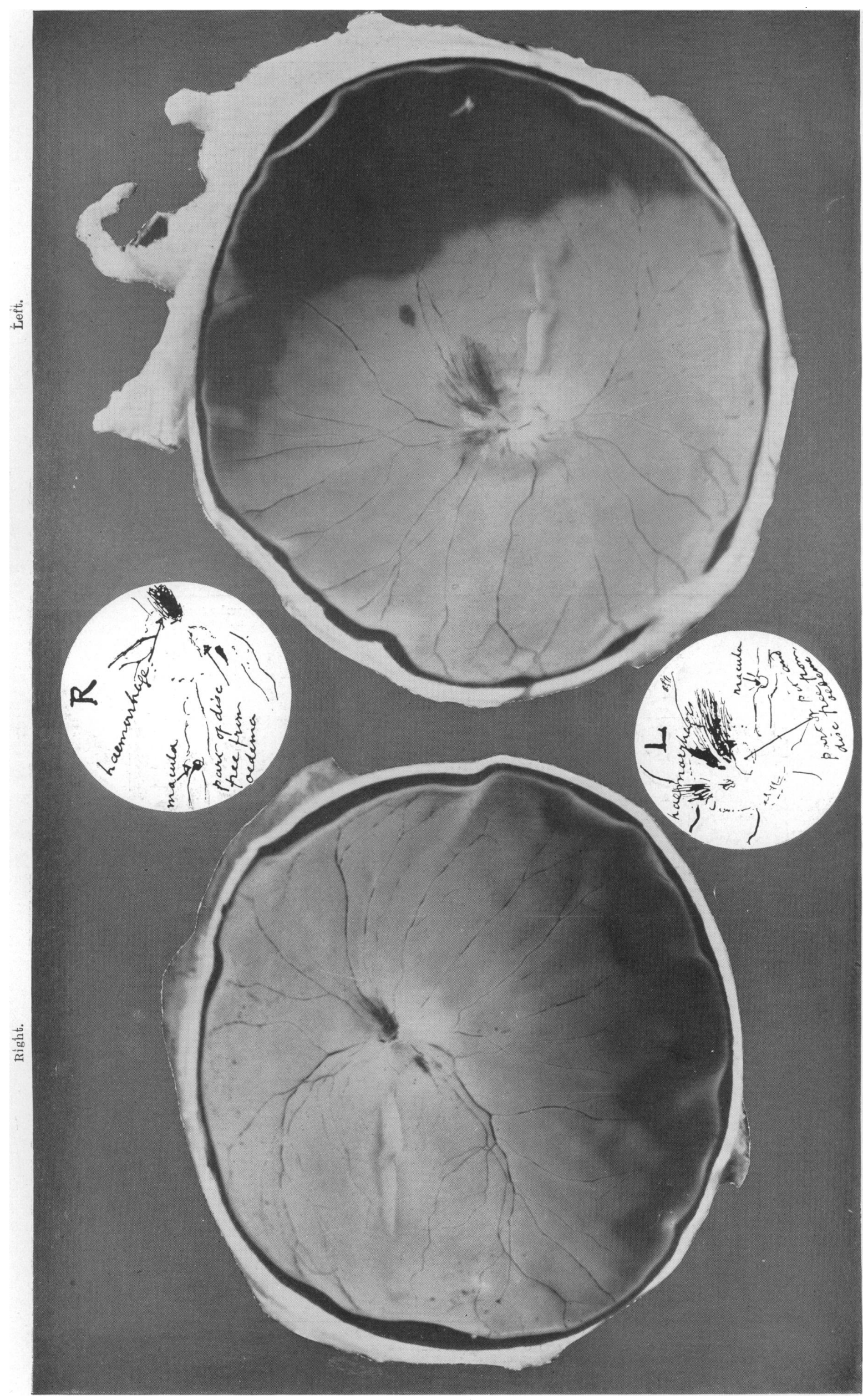




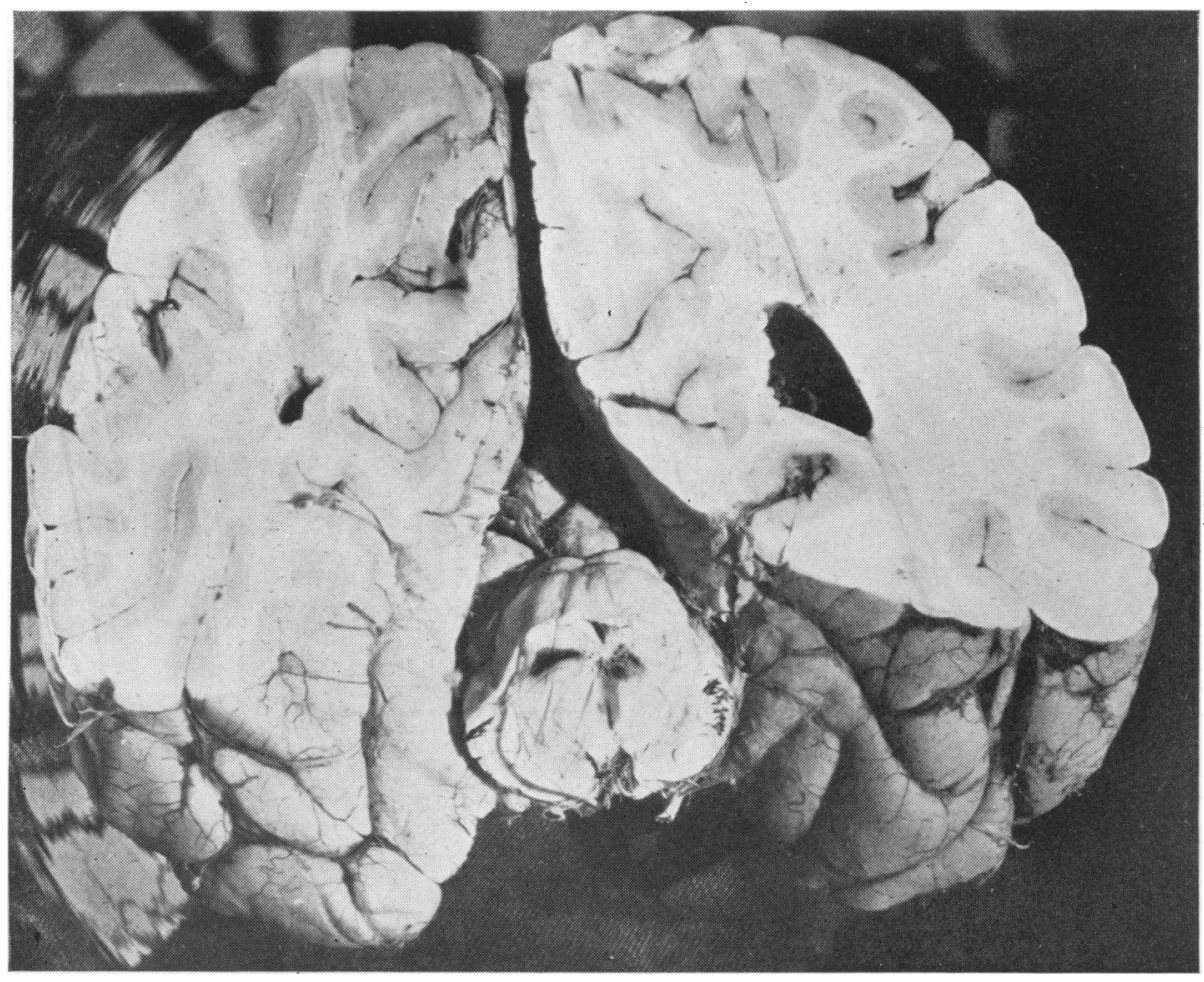

Fig. 7.-Brain from Case II. Mesencephalon divided, shows, besides scattered haemorrhages in the crus and brachium, a large haemorrhage in the right third nerve nucleus.

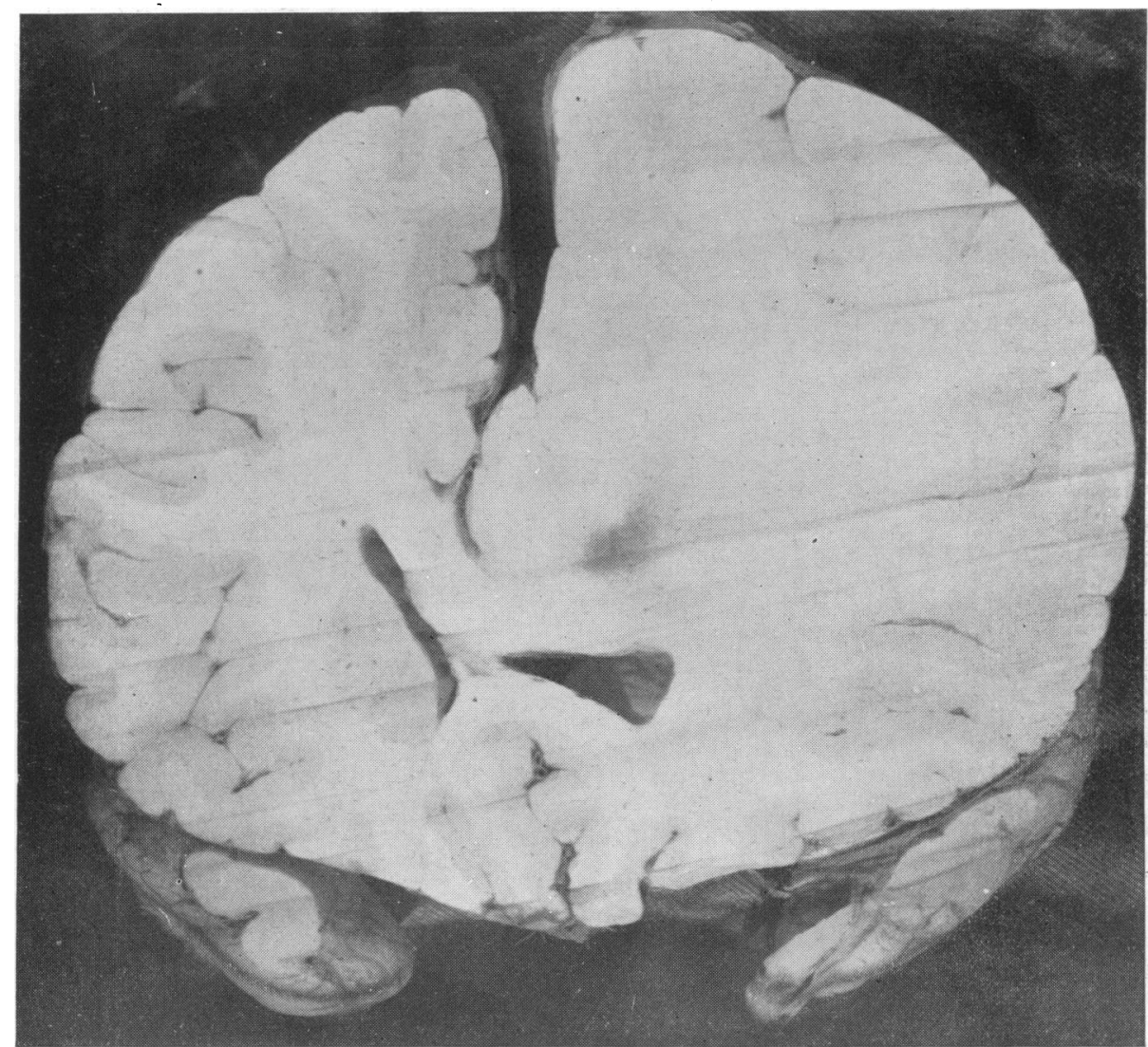

Fig. 8. - Brain from Case II. Viewed from the front, showing the distension of the left hemisphere by a tumour which has compressed and distorted the corpus callosum, showing that the pressure was
severest vertically over the right optic nerve. 


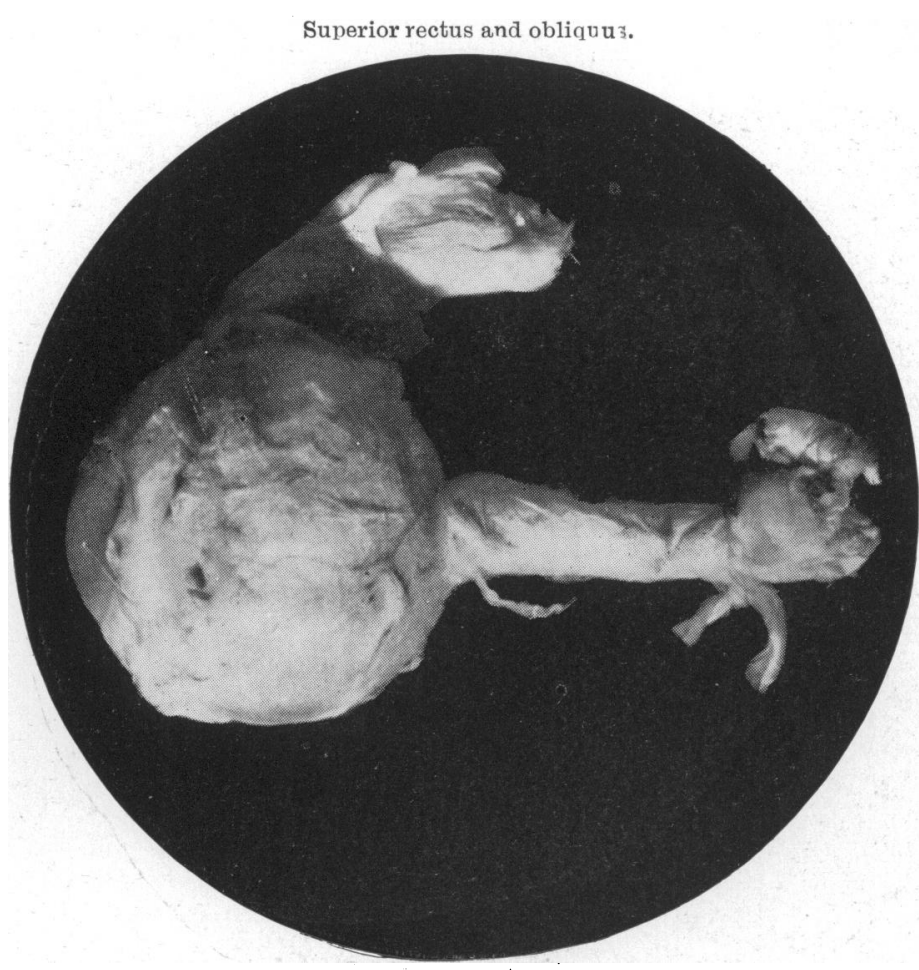

Fig. 9.-Early Optic Papilloedema. Eyeball and optic nerve from case of lateral recess cerebellar tumour (see Figs 5 and 6). Showing the ampulla due to dilatation of the sheath to be more marked on the dorsum of the nerve.

$$
\text { Superior oblique }
$$

$$
\text { muscle. }
$$

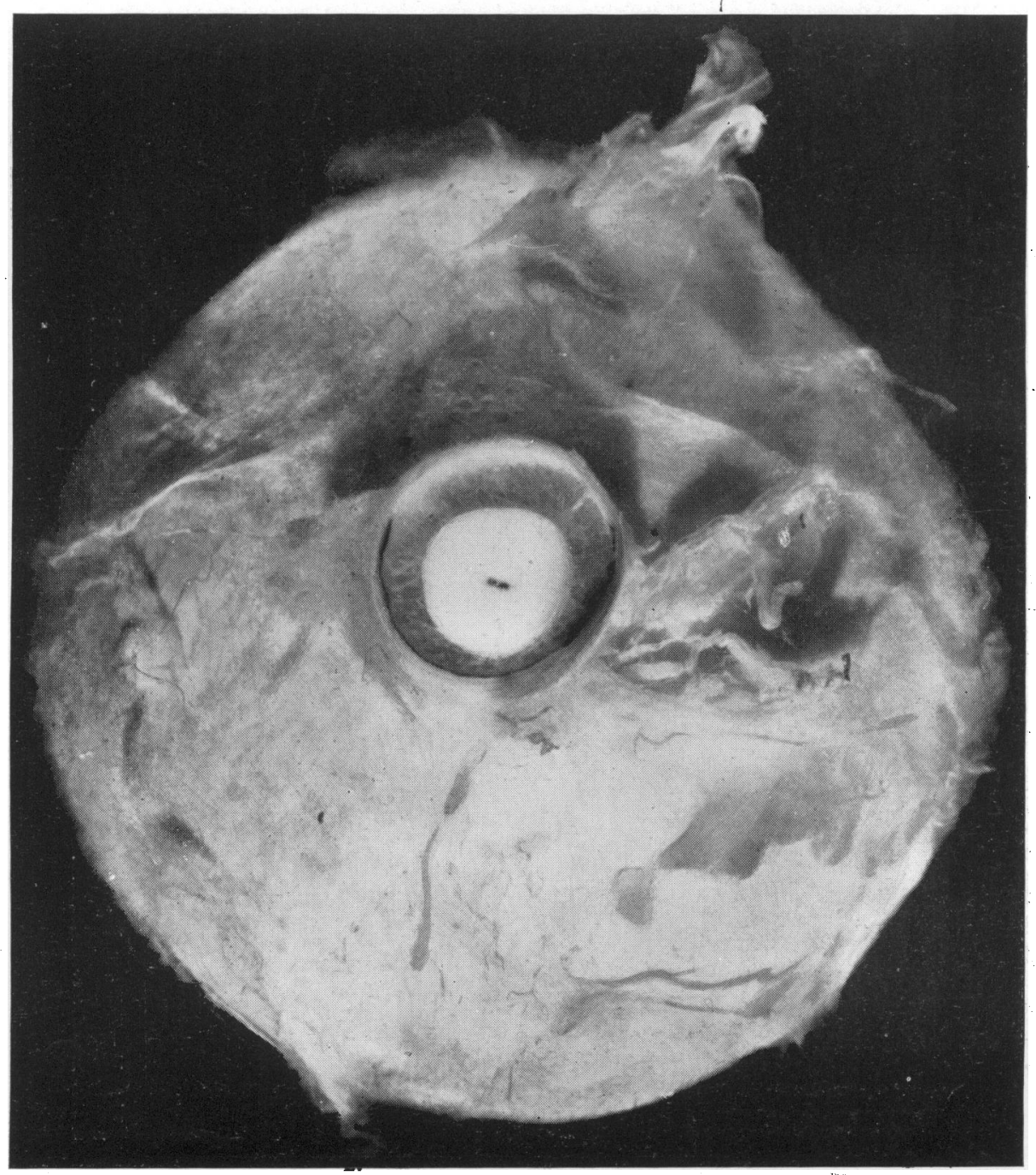

Fig. 10.-Transverse section of ampulla shown in profile in Fig. 9. The nerve sheath is seen to be more distended in the dorsal half. (Magnified 4 dium.) Case of lateral recess cerebellar tumour 


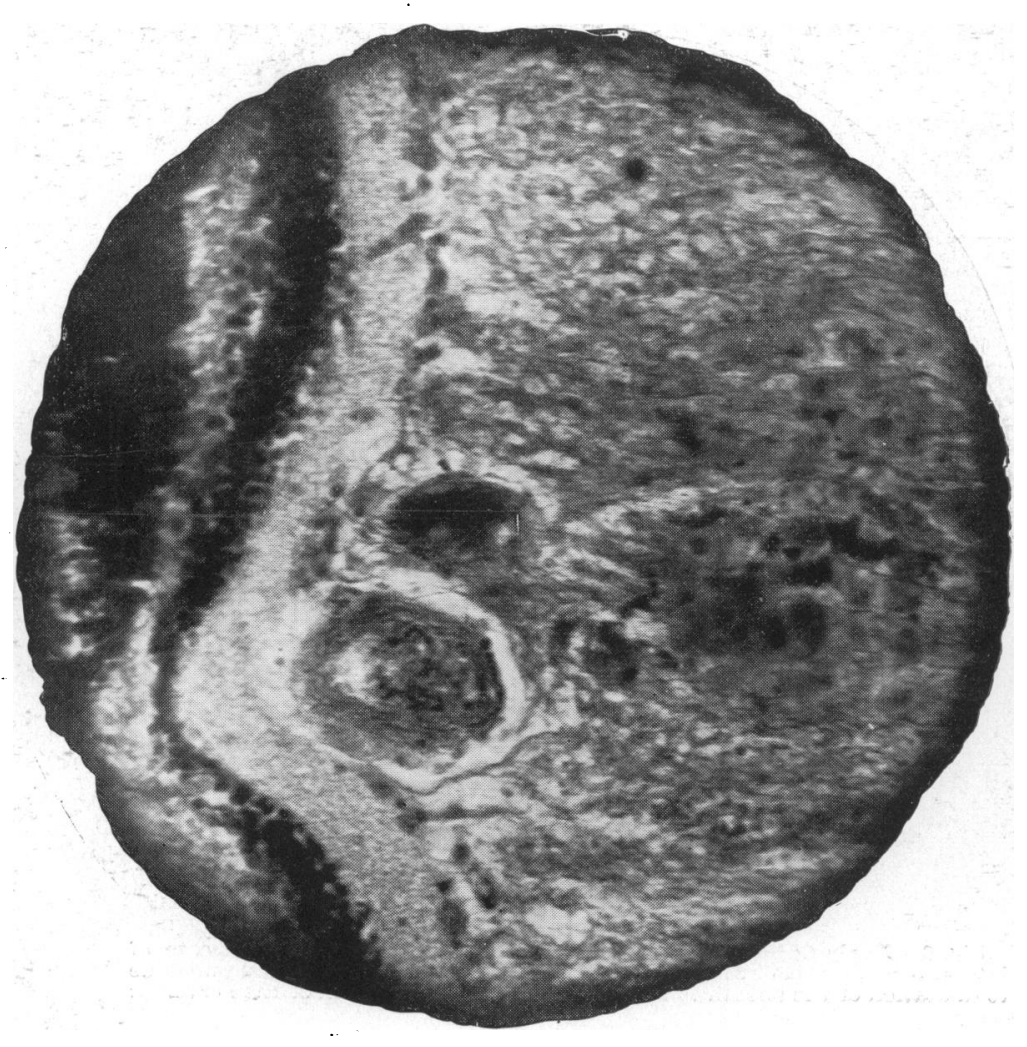

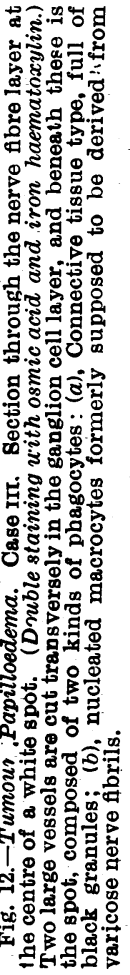

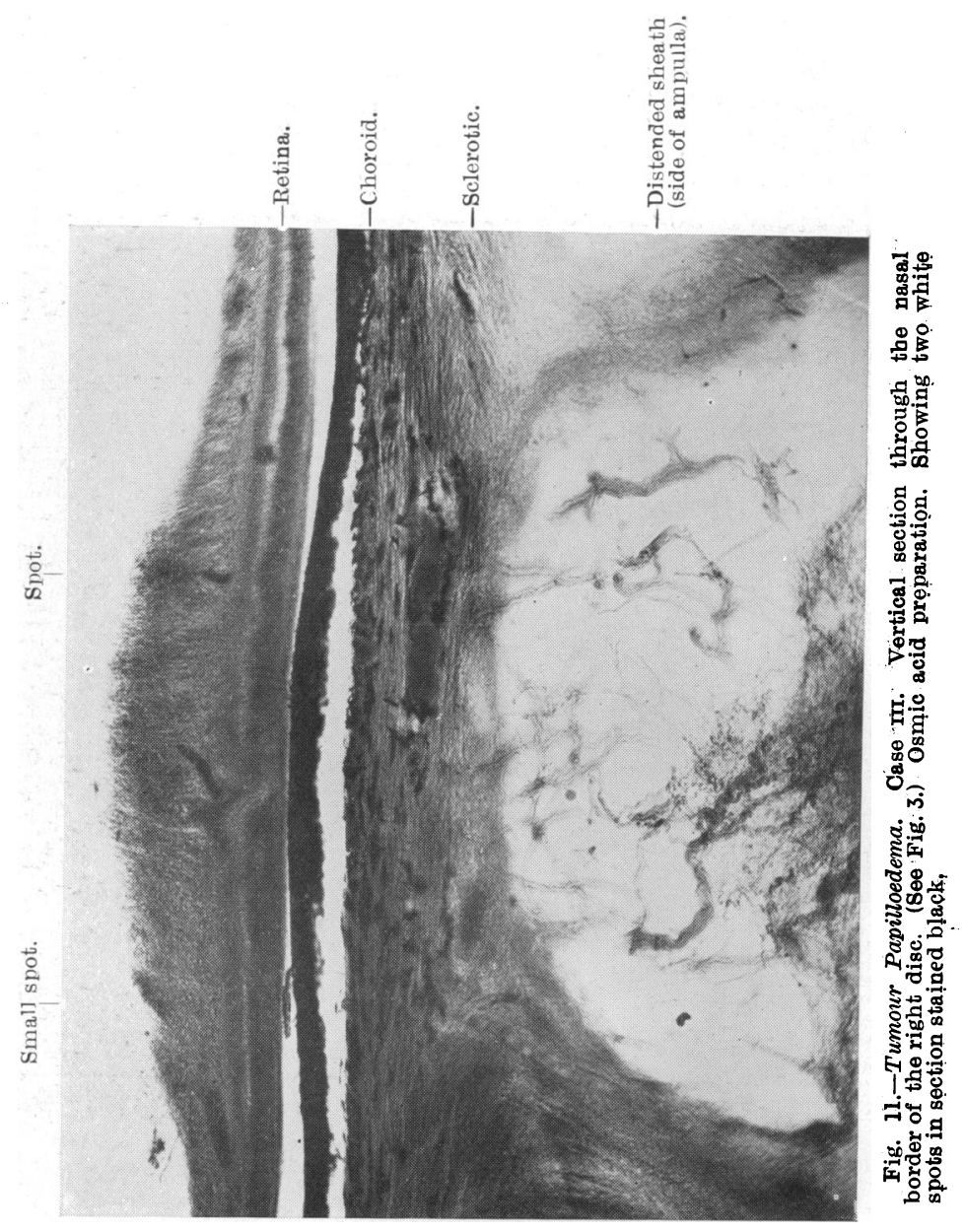




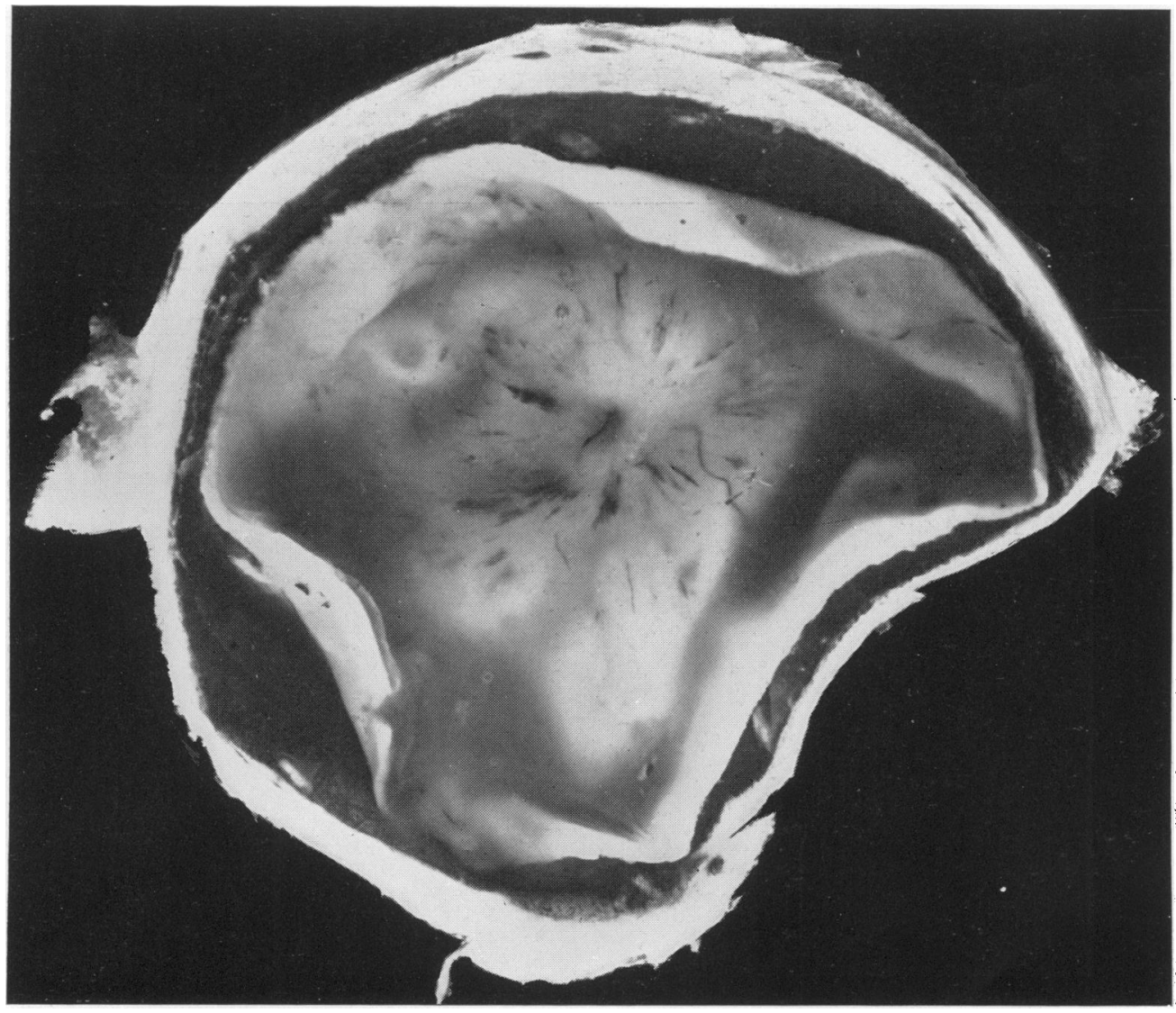

Fi 3. 13.-Albuminuric Retınitis. Fundus showing oedema of whole retina as well as papilla, numerous haemorrhages, and some white spots. The macula is seen swolled above and to outer side of disc.

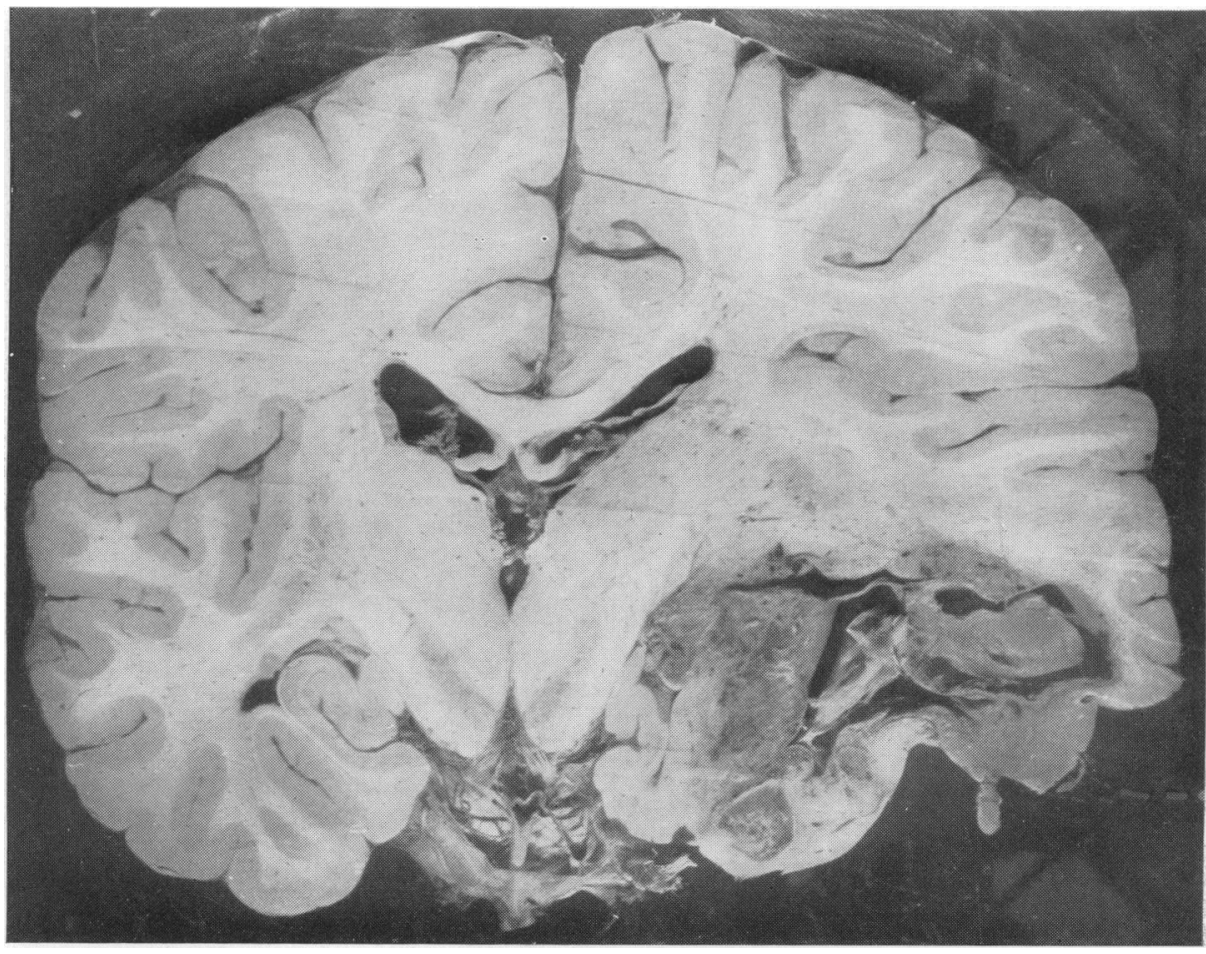

Fig. 14.-Brain from Case III. Showing tumour of left temporo-occipital region, comprising pons and red nucleus region of mesencephalon. See Figs. 1 and 2, showing the papilloedema to be severest on the
left side. 


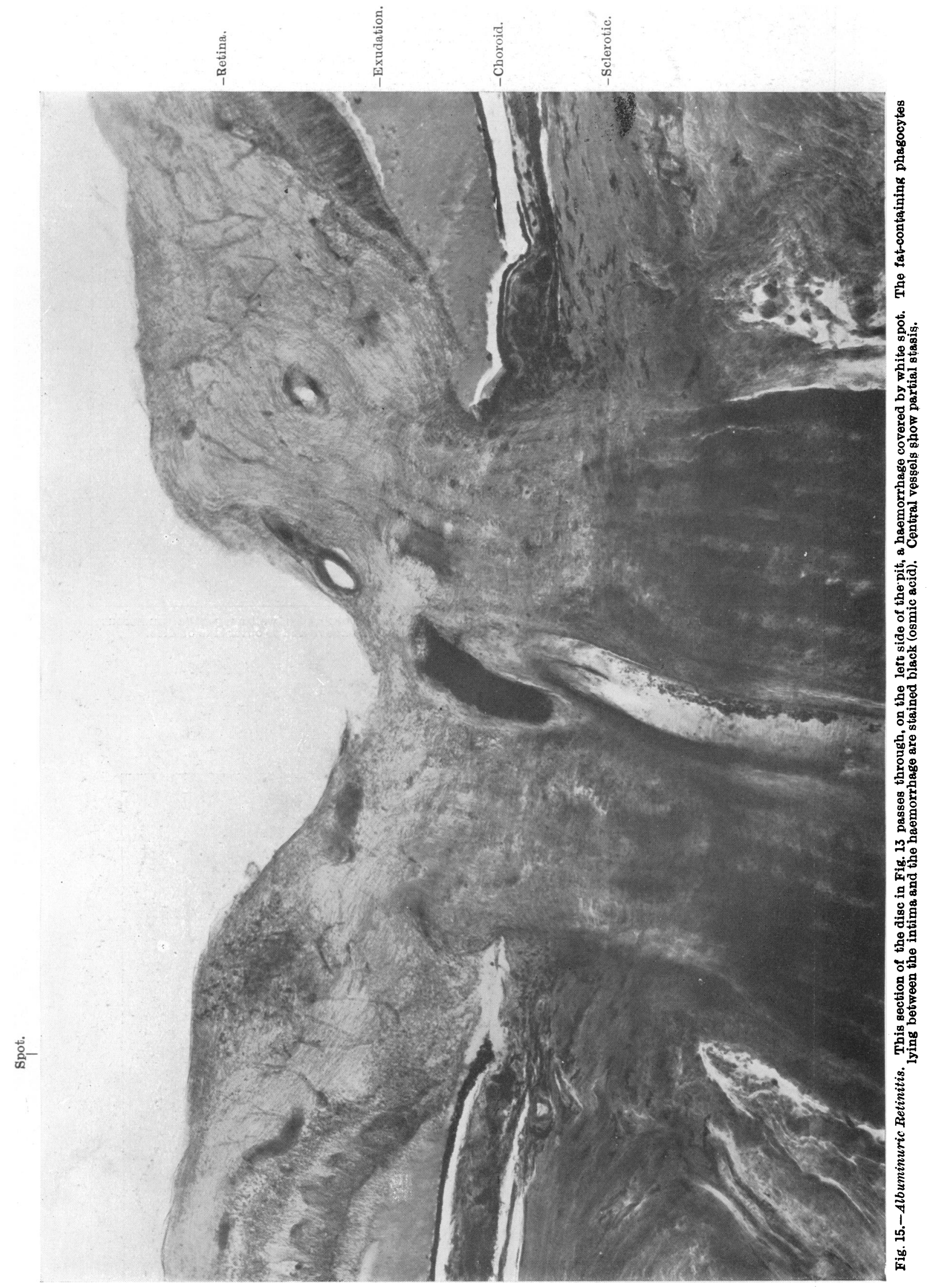



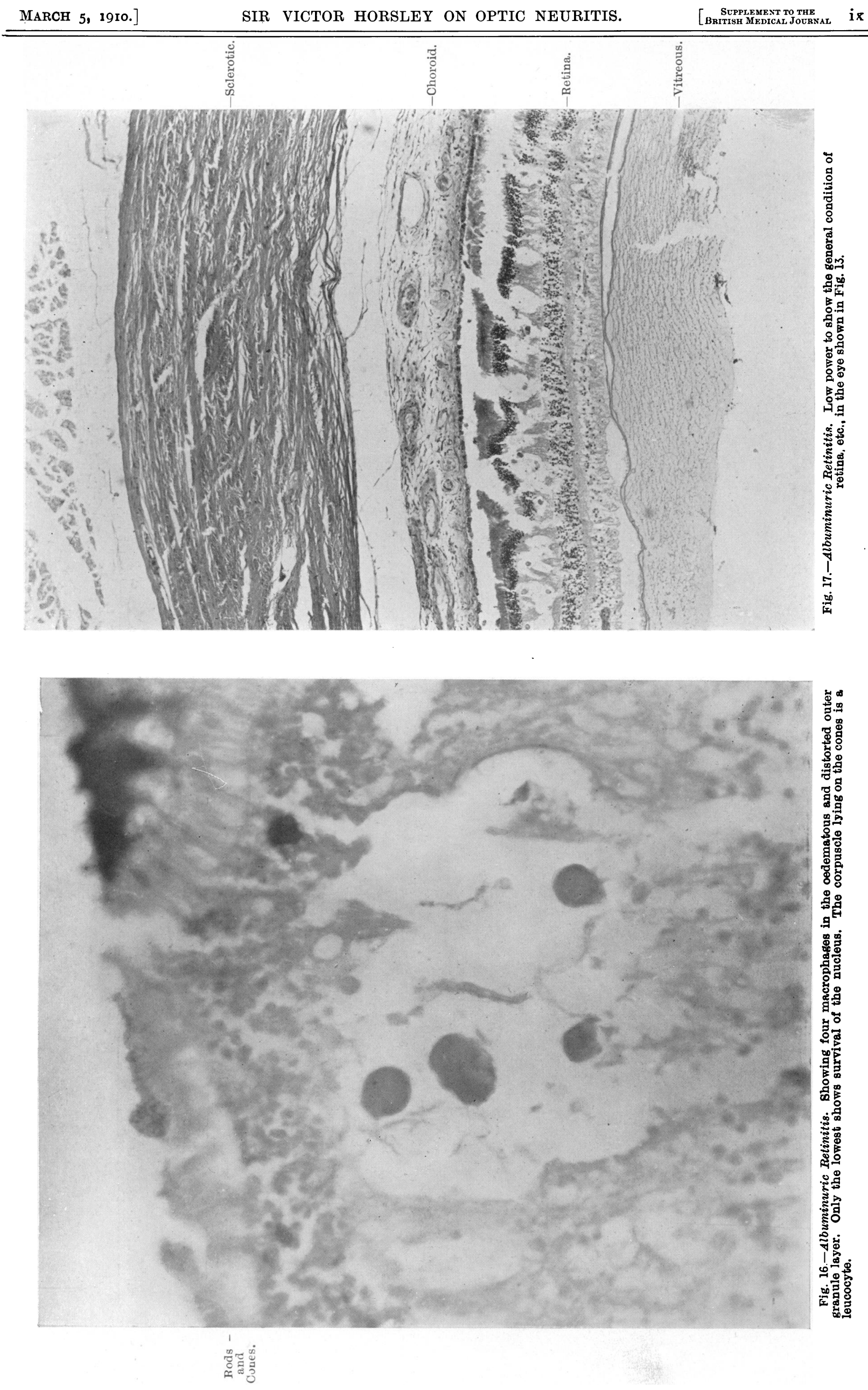


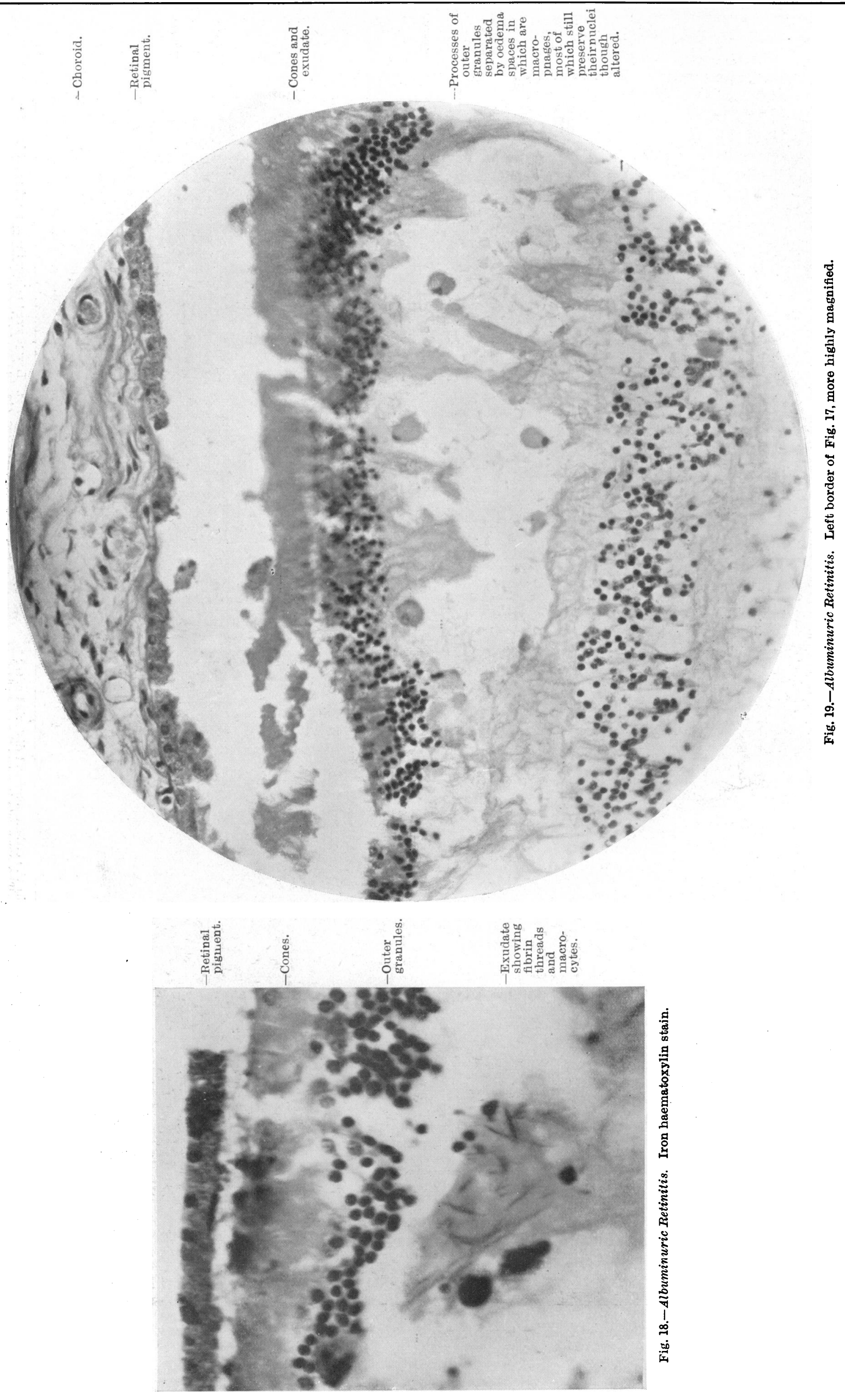




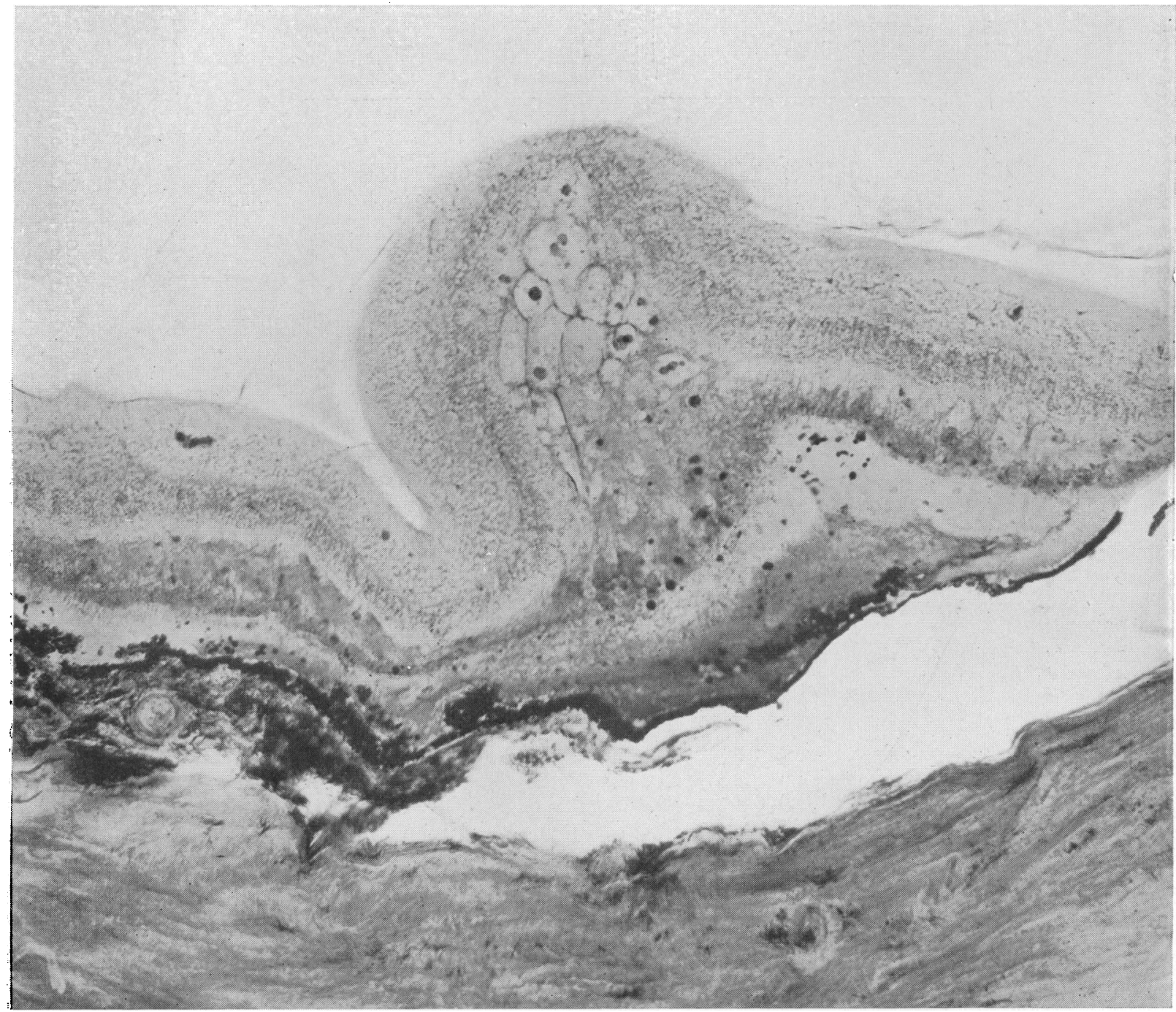

Fig. 20.-Albuminuric Retinitis. Osmic acid stain. Section through the swollen macula and fovea of Fig. 13 . The oedematous retina shows numerous macrophages in spaces as well as exudate, especially in the cone layer. The smaller corpuscles are leucocytes, containing fat granules or pigment granules.

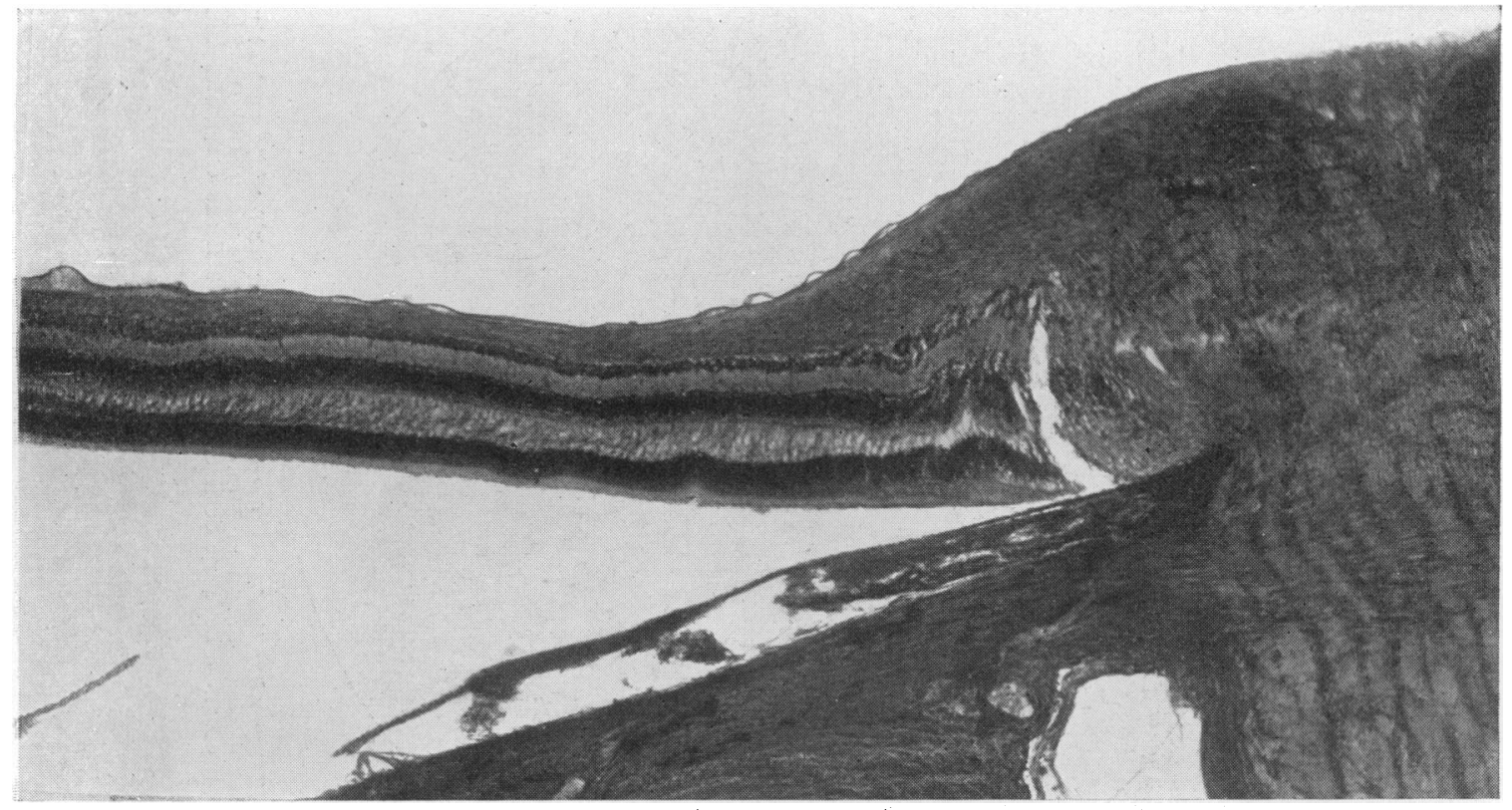

Fig. 21.- Section of macular side of disc in early papilloedema. The disc was dried to set up tension changes, which produced a macular star figure. The intima is shown thrown into ridges cut transversely. 




